\title{
The Distribution of Thirteen GABA Receptor Subunit mRNAs in the Rat Brain. III. Embryonic and Postnatal Development
}

\author{
D. J. Laurie, W. Wisden, and P. H. Seeburg \\ Laboratory of Molecular Neuroendocrinology, Center for Molecular Biology, University of Heidelberg, D-6900 Heidelberg, \\ Germany
}

The embryonic and postnatal expression of $13 \mathrm{GABA}_{\mathrm{A}}$ receptor subunit genes in the rat CNS was studied by in situ hybridization. Each transcript exhibited a unique regional and temporal developmental expression profile. For example, in both embryonic and early postnatal cortex and thalamus, expression of the $\alpha_{2}, \alpha_{3}, \alpha_{5}$, and $\beta_{3}$ mRNAs was pronounced. In particular, the $\alpha_{5}$ gene expression underwent a prominent peak in early brain. Subsequently, the thalamocortical expression of these four genes substantially diminished and was superseded in the adult by the $\alpha_{1}, \alpha_{4}, \beta_{2}$, and $\delta$ subunit mRNAs. Similarly, $\gamma_{1}$ and $\gamma_{3}$ gene expression also dropped markedly during development, their initial stronger expression being restricted to relatively few structures. In contrast, $\gamma_{2}$ gene expression was widespread and mostly remained constant with increasing age. The medial septum and globus pallidus were regions expressing few subunits in both early postnatal and adult stages, allowing clear developmental combinatorial changes to be inferred $\left(\alpha_{2} / \alpha_{3} \beta_{2} \gamma_{2}\right.$ to $\alpha_{1} \beta_{2} \gamma_{2}, \alpha_{2} / \alpha_{3} \beta_{2} \gamma_{1}$ to $\alpha_{1} \beta_{2} \gamma_{1} / \gamma_{2}$, respectively). In contrast, cerebellar Purkinje cells exhibited no developmental switch, expressing only the $\alpha_{1}, \beta_{2}, \beta_{3}$, and $\gamma_{2}$ mRNAs from birth to adult. Certain GABA transcripts were also detected in germinal zones (e.g., $\beta_{1}, \beta_{3}, \gamma_{1}$ ) and in embryonic peripheral tissues such as dorsal root ganglia (e.g., $\alpha_{2}, \alpha_{3}, \beta_{3}, \gamma_{2}$ ) and intestine $\left(\gamma_{3}\right)$. Some parallels in regional and temporal CNS expression were noted (e.g., $\alpha_{1} \beta_{2}, \alpha_{2} \beta_{3}, \alpha_{4} / \alpha_{6} \delta$ ), whereas the $\alpha_{5}$ and $\beta_{1}$ regional mRNA expressions converged over time. The changes of $\mathrm{GABA}_{A}$ receptor subunit gene expression suggest a molecular explanation for earlier observations on changing ligand binding affinities. Thus, the composition, and presumably properties, of embryonic/early postnatal rat GABA $_{A}$ receptors differs markedly from those expressed in the adult brain.

In the adult vertebrate brain, the inhibitory neurotransmitter GABA ( $\gamma$-aminobutyric acid) mediates fast inhibitory neurotransmission by gating chloride channels intrinsic to $\mathrm{GABA}_{\mathrm{A}}$

\footnotetext{
Received Jan. 31, 1992; revised Apr. 27, 1992; accepted May 28, 1992.

We gratefully acknowledge Dr. II. Monyer for aid with dissections, Ulla Keller for expert technical help, and Jutta Rami and Barbara Laurie for efficient secretarial skills. D.J.L. was in receipt of a European Science Exchange Programme fellowship awarded by the Royal Society (London). W.W. held an EMBO long-term fellowship. This work was supported by Bundesministerium fur Forschung und Technologie Grant BCT 364 Az 231/7291, the Deutsche Forschungsgemeinschaft (SFB 317, B9), and the Fonds der Chemischen Industrie to P.H.S

Correspondence should be addressed to D. J. Laurie, Laboratory of Molecular Neuroendocrinology, Zentrum für Molekulare Biologie, University of Heidelberg, Im Neuenheimer Feld 282, D-6900 Heidelberg, Germany.

Copyright (c) 1992 Society for Neuroscience $0270-6474 / 92 / 124151-22 \$ 05.00 / 0$
}

receptors (Olsen and Tobin, 1990). Although both GABAergic neurons and high levels of GABA are found in the fetal and neonatal CNS (Coyle and Enna, 1976; Lauder et al., 1986; Seress and Ribak, 1988; Meinecke and Rakic, 1990; Cobas et al., 1991), the role of the perinatal $\mathrm{GABA}_{\mathrm{A}}$ system appears to differ substantially from that in adult CNS. For example, the immature brain is poorly protected against seizure disorders by the $\mathrm{GABA}_{\mathrm{A}}$ system (Aicardi and Chevrie, 1970; Mecarelli et al., 1988). In the fetal and neonatal hippocampus, GABA-activated chloride channels lead to marked membrane depolarization (Ben-Ari et al., 1989; reviewed by Cherubini et al., 1991). Furthermore, activation of neonatal $\mathrm{GABA}_{\mathrm{A}}$ receptors induces a rise in intracellular calcium concentration in both cerebellar and cortical neurons (Connor et al., 1987; Yuste and Katz, 1991), probably as a result of membrane depolarization and activation of voltage-sensitive calcium channels. Raised intracellular calcium is an important factor in neuronal growth and differentiation (Kater and Guthrie, 1990; Spitzer, 1991). Consistent with this observation, in primary culture of several embryonic and neonatal brain tissues, GABA, perhaps in concert with glutamate, exerts a variety of pronounced neurotrophic actions, including promotion of neurite extension, synaptogenesis, and the synthesis of its own receptors (Hansen et al., 1987; Meier et al., 1987; Wolff et al., 1987; Kater and Guthrie, 1990). Consistent with an important role of $\mathrm{GABA}_{\mathrm{A}}$ receptors in development, experimental administration of benzodiazepines during pregnancy causes biochemical and behavioral manifestations in the progeny that can persist into adulthood (Simmons et al., 1984a,b; Kellogg, 1988).

Perhaps commensurate with the different roles of GABA in the neonate and adult, the pharmacological properties of GA$\mathrm{BA}_{\mathrm{A}}$ receptors change during rat and primate brain development. For example, the proportions of $\mathrm{GABA}_{\mathrm{A}}$ and benzodiazepine $(B Z)$ receptor subtypes alter, with low-affinity $G_{A B A}$ receptors appearing later than those of high affinity, and type II and I BZ receptors predominating in the neonate and adult, respectively (Chisholm et al., 1983; Madtes, 1987; Meier et al., 1987; Reichelt et al., 1991).

The subunit composition of perinatal $\mathrm{GABA}_{\mathrm{A}}$ receptors remains undefined. $\mathrm{GABA}_{\mathrm{A}}$ receptors are believed to be pentameric and composed, in unknown ratios, of subunits from several related sequence classes (Unwin, 1989). In the rodent, 13 subunit genes have been identified and subdivided into $\alpha, \beta, \gamma$, and $\delta$ classes (reviewed by Olsen and Tobin, 1990; Seeburg et al., 1990; Lüddens and Wisden, 1991; Wisden and Seeburg, 1992). The properties of recombinant $\mathrm{GABA}_{\mathrm{A}}$ receptors depend upon the subunits from which they are assembled (Lüddens and Wisden, 1991; Wisden and Seeburg, 1992). Regional differences 

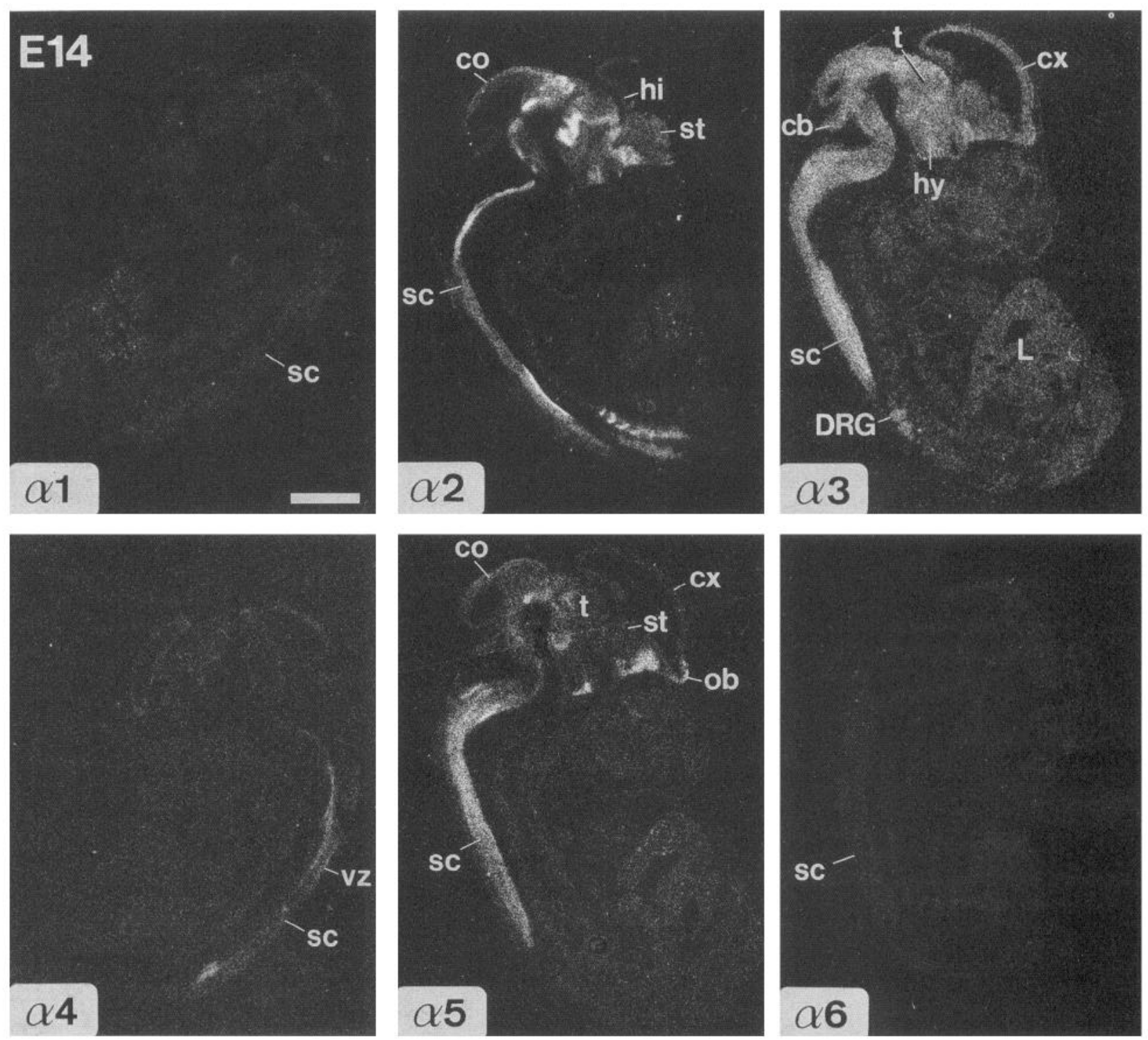

Figure 1. X-ray film autoradiographs illustrating distribution of GABA receptor $\alpha_{1}-\alpha_{6}$ mRNAs in sagittal sections of E14 rat embryos. See Appendix for abbreviations. The apparent labeling of liver by some probes was nonspecific. Scale bar, $2 \mathrm{~mm}$.

in subunit gene expression (Laurie et al., 1992; Wisden et al., 1992) could therefore account for the pharmacological diversity of $\mathrm{GABA}_{\mathrm{A}}$ receptors in the adult rat CNS (Unnerstall et al., 1981; Young et al., 1981; Niddam et al., 1987; Olsen et al., 1990 ), and probably also underlie the changing $\mathrm{GABA}_{\mathrm{A}}$ pharmacology during development. Northern and Western analyses have indicated age-related changes in $\alpha_{1}, \alpha_{2}, \alpha_{3}, \alpha_{5}$, and $\beta_{1}$ subunit expression in rat brain, but have not shown in detail which brain regions are affected (Montpied et al., 1989; Garrett et al., 1990; MacLennan et al., 1991; McKernan et al., 1991a). Regional changes in expression of a limited number of subunit genes $\left(\alpha_{1}, \beta_{1}, \beta_{2}, \beta_{3}\right.$, and $\left.\gamma_{2}\right)$ in postnatally developing rat brain have been reported using in situ hybridization (Gambarana et al., 1990, 1991; Zhang et al., 1991). We recently mapped the mRNA distribution of the $13 \mathrm{GABA}_{\mathrm{A}}$ subunits $\left(\alpha_{1}-\alpha_{6}, \beta_{1}-\beta_{3}\right.$, $\gamma_{1}-\gamma_{3}, \delta$ ) in adult rat brain to deduce subunit combinations found in vivo (Laurie et al., 1992; Wisden et al., 1992). We have extended these studies with a comprehensive examination of GA$\mathrm{BA}_{\mathrm{A}}$ receptor subunit gene expression during both embryonic and postnatal development. We now report that expression of each $\mathrm{GABA}_{\mathrm{A}}$ receptor subunit gene changes during early development. These changes appear to coincide with the alteration of GABA's role from putatively excitatory, neurotrophic factor to inhibitory neurotransmitter.

\section{Materials and Methods}

For each GABA receptor subunit $\left(\alpha_{1}-\alpha_{6}, \beta_{1}-\beta_{3}, \gamma_{1}-\gamma_{3}, \delta\right)$, a unique 45 base antisense oligonucleotide was employed. Note that the subunit termed $\alpha_{5}$ by us and others (Malherbe et al., 1990; Pritchett and Seeburg, 1990) has also been termed $\alpha_{4}$ by Khrestchatisky et al. (1989). The $\alpha_{4}$ subunit referred to in this article is as described by Ymer et al. (1989) and Wisden et al. (1991a). The oligonucleotide sequences and experimental procedures (labeling, hybridization, posthybridization washing) were as described by Wisden et al. (1991b, 1992). Probes were 3' endlabeled using terminal deoxynucleotidyl transferase (Bethesda Research Labs) and a 30:1 molar ratio of $\left(\alpha-{ }^{35}\right)$ dATP $(1200 \mathrm{Ci} / \mathrm{mmol}$; Amersham). Nonperfused rat brains or whole rat embryos were removed and frozen on dry ice prior to sectioning on a cryotome. In situ hybridization was performed on sagittal sections $(14 \mu \mathrm{m})$ of whole embryos of 14 17 , and $19 \mathrm{~d}$ of gestation (E14, E17, and E19), and on horizontal sections 

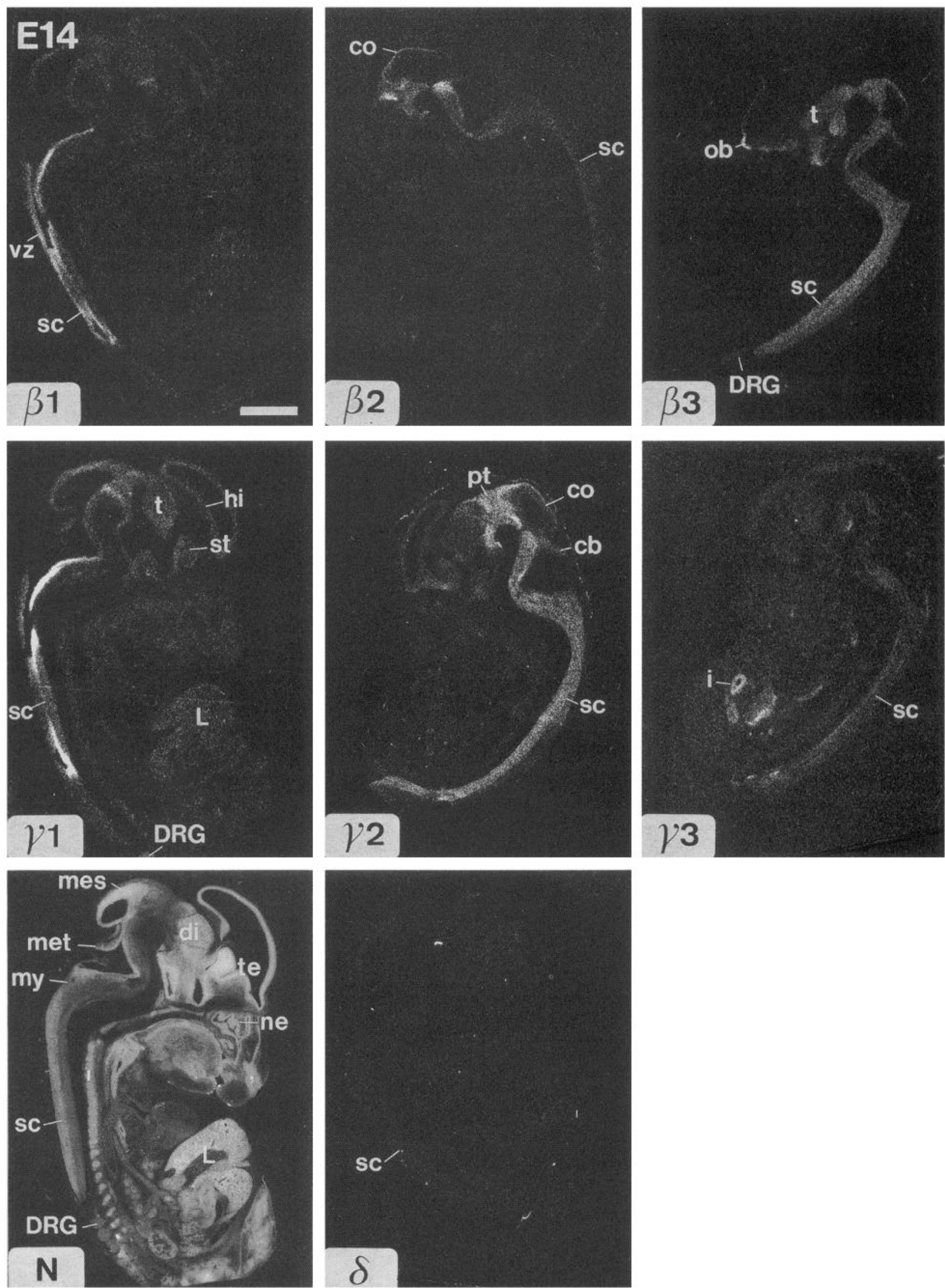

Figure 2. X-ray film autoradiographs illustrating distribution of GABA $A_{A}$ receptor $\beta_{1}-\beta_{3}, \gamma_{1}-\gamma_{3}$, and $\delta$ mRNAs in sagittal sections of E14 rat embryos. $N$, Nissl (thionin) stain of whole embryo section. See Appendix for abbreviations. The apparent labeling of liver by some probes was nonspecific. Scale bar, $2 \mathrm{~mm}$. 

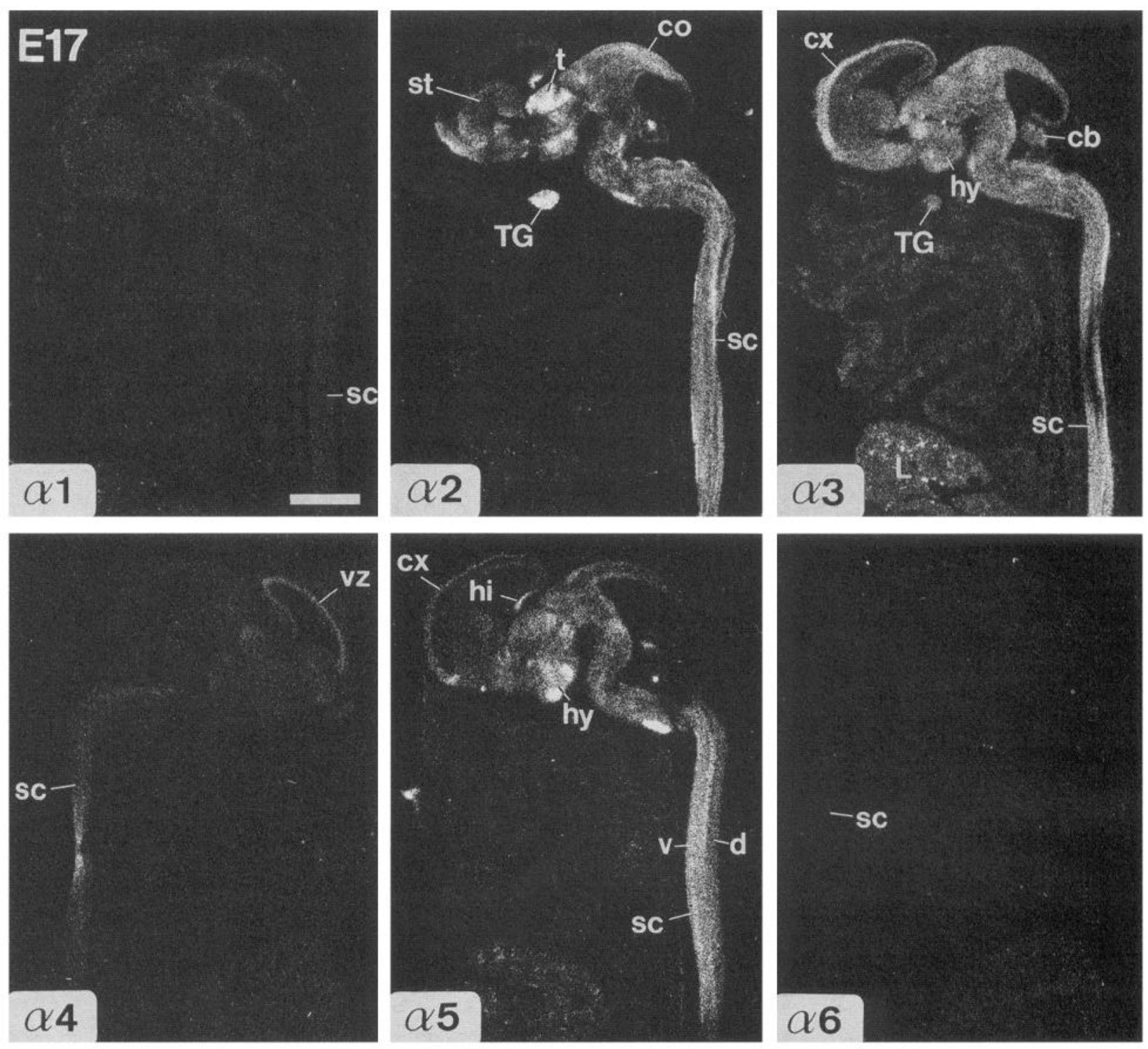

Figure 3. X-ray film autoradiographs illustrating distribution of GABA $A_{A}$ receptor $\alpha_{1}-\alpha_{6}$ mRNAs in sagittal sections of E17 rat embryos. See Appendix for abbreviations. The apparent labeling of liver by some probes was nonspecific. Scale bar, $2 \mathrm{~mm}$.

of brains taken from rats of postnatal ages 0,6 , and $12 \mathrm{~d}(\mathrm{P} 0, \mathrm{P} 6, \mathrm{P} 12)$ and from adult males. Embryonic ages were calculated from the end of a $4 \mathrm{hr}$ mating period and confirmed by examination of paw development (Rugh, 1991). P0 indicates the day of birth. Sex determination was performed only on adult rats. In order to confirm developmental changes, two sections from each of three animals at each age were hybridized and examined for each probe. After hybridization [ $50 \%$ formamide, $4 \times$ saline-sodium citrate (SSC), $10 \%$ dextran sulfate; $\left.42^{\circ} \mathrm{C}\right]$ and washing $\left(1 \times \mathrm{SSC}, 60^{\circ} \mathrm{C}\right)$, sections were exposed to Kodak SB-5 film or dipped in photographic emulsion (Ilford K5). Anatomy of autoradiographs and thionin-stained sections was determined using the atlases of Paxinos and Watson (1986) and Paxinos et al. (1991). Microscopic examination of emulsion-coated sections was performed for every described structure in order to determine the cellular locations reported. Signal specificity was assessed by competition experiments in which radiolabeled probes were hybridized to sections in the presence of excess ( 100 -fold) unlabeled probe. This resulted in virtually blank autoradiographs, except for some nonspecific labeling of peripheral tissues. The assessment of the specificity of the probes has been described previously (Wisden et al., 1992). Photomicrographs were obtained using a Zeiss Axioplan microscope under bright- and dark-field optics.

Expression levels of representative mRNAs $\left(\alpha_{1}, \alpha_{2}, \alpha_{5}, \beta_{3}, \gamma_{2}\right)$ were quantified in selected brain regions by measurement of $\mathrm{x}$-ray film optical densities using an Amersham RAS optical densitometric system. The weak signals due to nonspecific hybridization in each region were subtracted from the corresponding total hybridization value to yield a value for specific hybridization. The values from three subjects were averaged.

\section{Results}

In the developing brain, a specific regional and temporal expression pattern occurred for each of the $13 \mathrm{GABA}_{\mathrm{A}}$ receptor subunit mRNAs (illustrated in Figs. 1-15, with quantified values presented in Fig. 16; summarized in Tables 1 and 2). Embryonic stage E14 was chosen as an initiation point as this age is prior to generation, migration, and differentiation of most telencephalic and mesencephalic neurons (Jacobson, 1978; Jones, 1985). The $\alpha_{1}, \alpha_{6}$, and $\delta$ mRNAs appeared postnatally and increased in expression markedly with age (see Table 2 ). The transcript for $\alpha_{6}$ was confined to the postnatal cerebellum. (Note that in this context, the term "transcript" used throughout the text denotes mature mRNA and not necessarily the primary mRNA.) The $\beta_{2}$ and $\gamma_{2}$ transcripts were present in the embryo, and their 

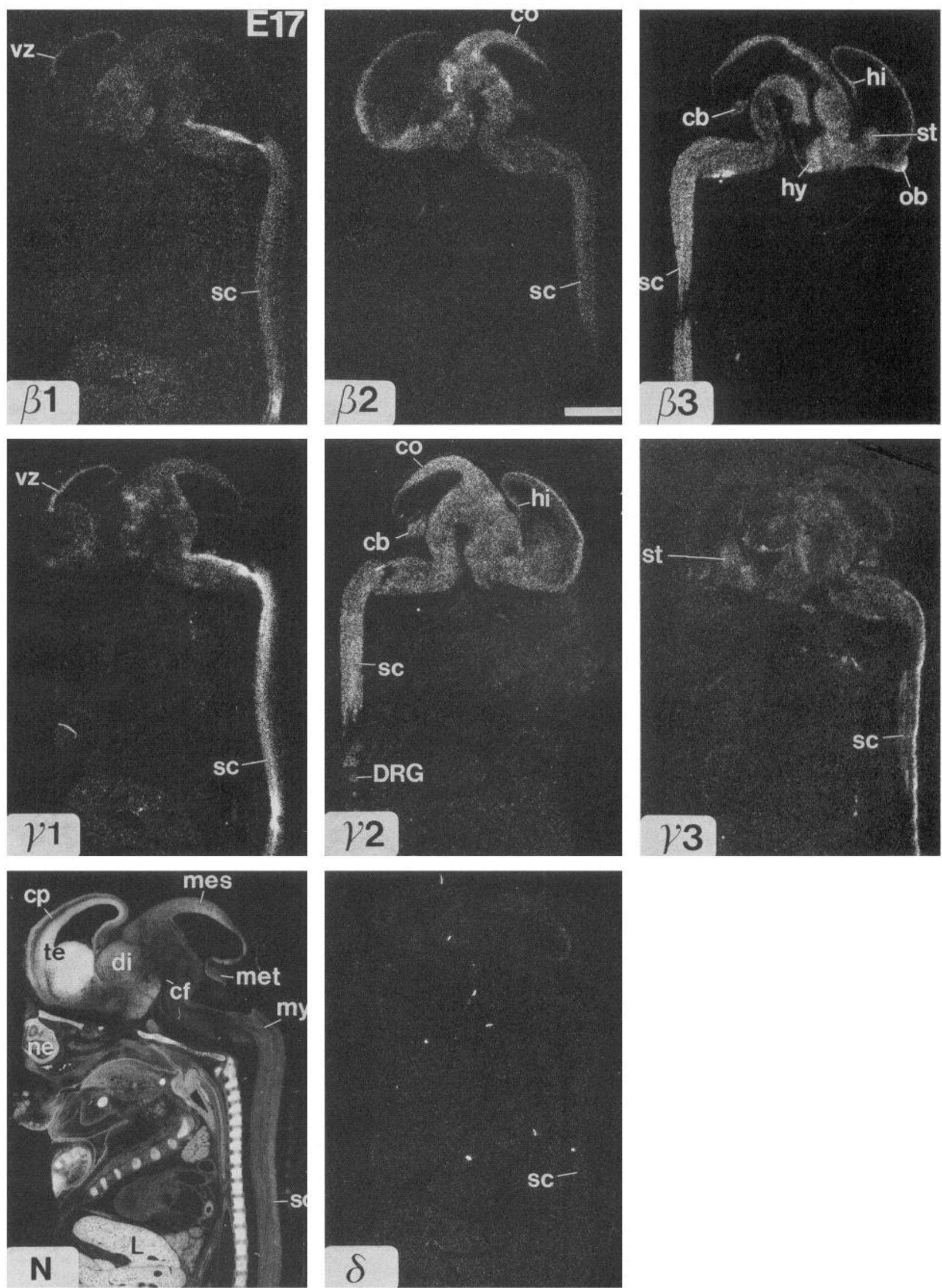

Figure 4. X-ray film autoradiographs illustrating distribution of GABA $\mathrm{A}_{\mathrm{A}}$ receptor $\beta_{1}-\beta_{3}, \gamma_{1}-\gamma_{3}$, and $\delta$ mRNAs in sagittal sections of E17 rat embryos. $N$, Nissl (thionin) stain of whole embryo section. See Appendix for abbreviations. The apparent labeling of liver by some probes was nonspecific. Scale bar, $2 \mathrm{~mm}$. 

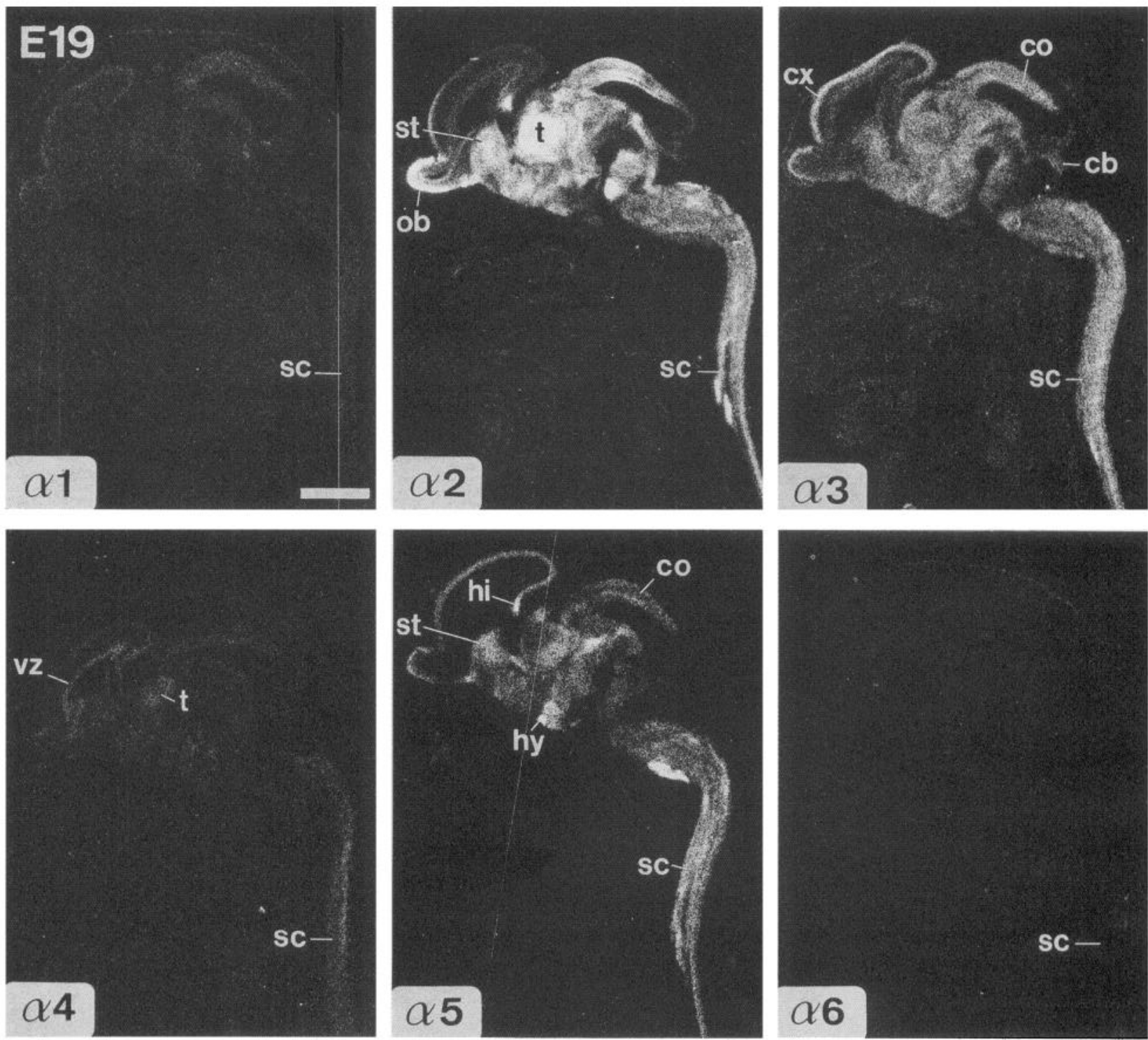

Figure 5. X-ray film autoradiographs illustrating distribution of GABA, receptor $\alpha_{1}-\alpha_{6}$ mRNAs in sagittal sections of E19 rat embryos. See Appendix for abbreviations. The apparent labeling of liver by some probes was nonspecific. Scale bar, $2 \mathrm{~mm}$.

\begin{tabular}{|c|c|c|}
\hline Structure & Perinate (E19-P6) & Adult \\
\hline \multicolumn{3}{|l|}{ Olfactory bulb } \\
\hline Mitral cells & $\begin{array}{l}\alpha_{1} \alpha_{2} \alpha_{3}\left(\alpha_{4}\right) \alpha_{5} \\
\beta_{1} \beta_{2} \beta_{3} \gamma_{1} \gamma_{2}\end{array}$ & $\begin{array}{l}\alpha_{1}\left(\alpha_{3} \alpha_{4}\right) \\
\beta_{1} \beta_{2} \beta_{3} \gamma_{2}\end{array}$ \\
\hline Thalamus & $\alpha_{2} \alpha_{3} \alpha_{4} \alpha_{5} \beta_{3} \gamma_{1}$ & $\alpha_{1} \alpha_{4} \beta_{2} \delta$ \\
\hline Medial septum & $\alpha_{2} \alpha_{3} \beta_{2} \gamma_{2}$ & $\alpha_{1} \beta_{2} \gamma_{2}$ \\
\hline \multicolumn{3}{|l|}{ Striatum } \\
\hline Caudate & $\alpha_{2} \alpha_{5} \beta_{3}\left(\gamma_{3}\right)$ & $\alpha_{2} \alpha_{4} \beta_{3} \delta$ \\
\hline Globus pallidus & $\alpha_{2}\left(\alpha_{3}\right) \beta_{2} \gamma_{1}$ & $\alpha_{1} \beta_{2}\left(\gamma_{1} \gamma_{2}\right)$ \\
\hline \multicolumn{3}{|l|}{ Cerebellum } \\
\hline Purkinje cells & $\alpha_{1} \beta_{2} \beta_{3} \gamma_{2}$ & $\alpha_{1} \beta_{2} \beta_{3} \gamma_{2}$ \\
\hline \multirow[t]{2}{*}{ Granule cells } & $\left(\alpha_{1} \alpha_{2} \alpha_{3} \alpha_{4} \alpha_{6}\right)$ & $\alpha_{1} \alpha_{6} \beta_{2} \beta_{3} \gamma_{2} \delta$ \\
\hline & $\left(\beta_{1} \beta_{2} \beta_{3} \gamma_{1} \gamma_{2} \gamma_{3}\right)$ & \\
\hline
\end{tabular}

Parentheses indicate lesser, but not insignificant, levels of expression. Adult expression data were constructed from Wisden et al. (1992), Laurie et al. (1992), and present results. expression increased after birth. In contrast, a postnatal decline in expression was observed for $\alpha_{3}$ mRNA, which was abundant in the embryo. Finally, a third pattern involving a peak of expression was apparent for $\alpha_{2}$ (E19-P6), $\alpha_{4}$ (P12), $\alpha_{5}$ (P6), $\beta_{1}$ (P6$\mathrm{P} 12), \beta_{3}$ (P12), $\gamma_{1}(\mathrm{P} 0-\mathrm{P} 6)$, and $\gamma_{3}$ (P6) transcripts (see Table 2). Regional expression changes are described below. Since expression was not examined between P12 and adult ages, descriptions of peak expression at P12 relate to comparison of P12 and adult levels and do not preclude the possibility of maximal expression at a later age.

\section{Cortex}

In neurons of the developing rat cortex, considerable changes occurred between the principal subunit mRNAs expressed perinatally and in maturity. The $\alpha_{3}$ transcript was the most prominent throughout pre- and early postnatal development (Figs. 1-7), declining after P12 to relatively low adult levels (Figs. 913, Table 2). The $\alpha_{2}$ and $\alpha_{5}$ mRNAs appeared later in cortical neurons (E17/E19; Figs. 3, 5), quickly increased (four- and two- 

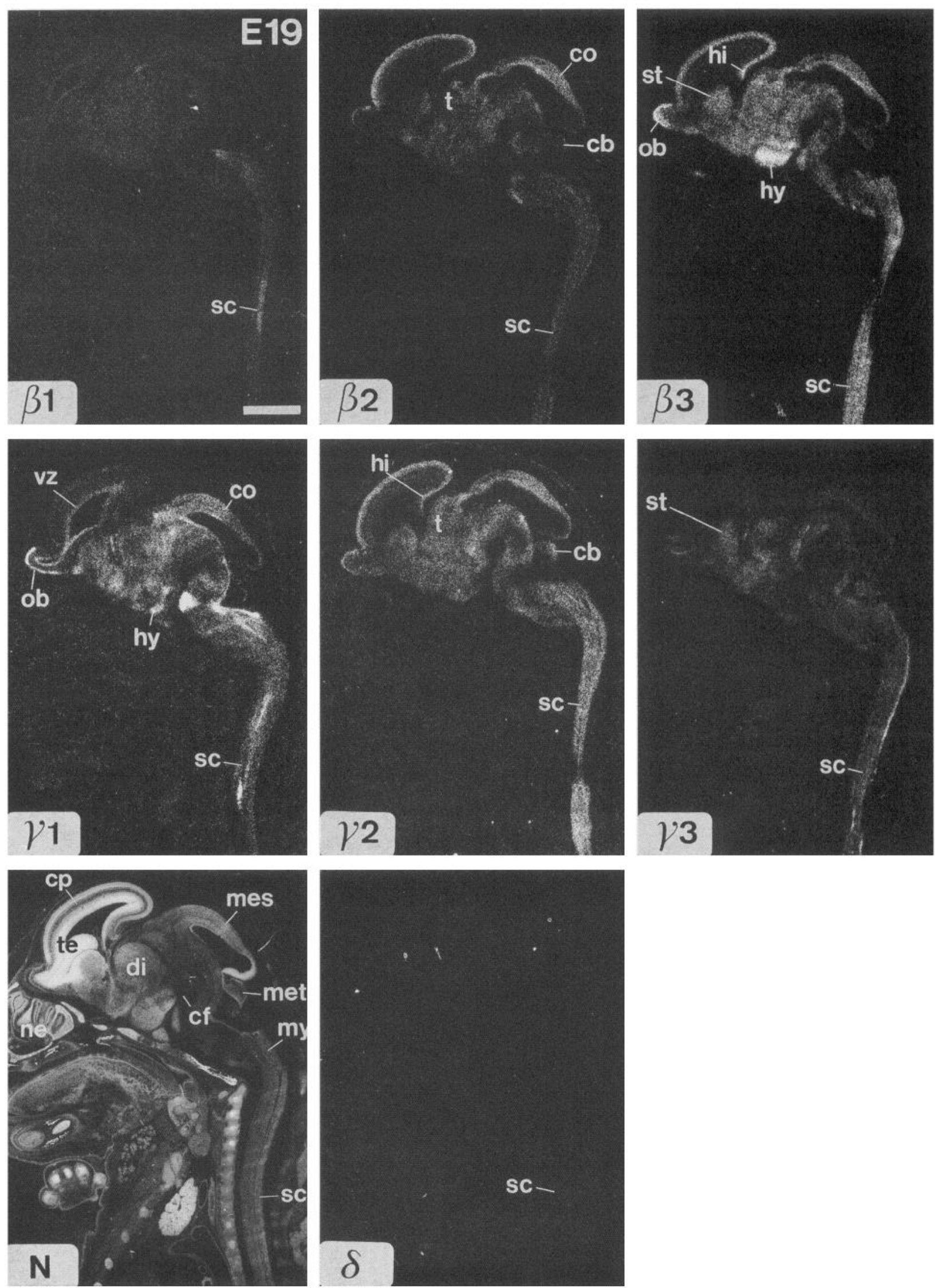

Figure 6. X-ray film autoradiographs illustrating distribution of $\mathrm{GABA}_{\mathrm{A}}$ receptor $\beta_{1}-\beta_{3}, \gamma_{1}-\gamma_{3}$, and $\delta \mathrm{mRNAs}$ in sagittal sections of E19 rat embryos. $N$, Nissl (thionin) stain of whole embryo section. See Appendix for abbreviations. The apparent labeling of liver by some probes was nonspecific. Scale bar, $2 \mathrm{~mm}$. 

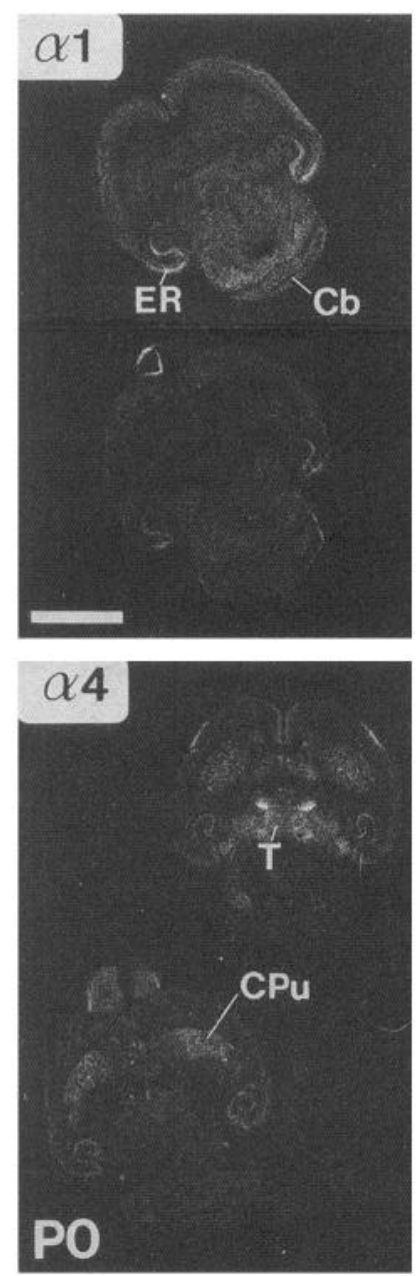



Figure 7. X-ray film autoradiographs illustrating distribution of GABA $\mathrm{Ar}$ ceptor $\alpha_{1}-\alpha_{6}$ mRNAs in horizontal sections of P0 rat brain. See Appendix for abbreviations. Scale bar, $4 \mathrm{~mm}$. fold, respectively, in whole neocortex as measured by optical densities) to prominent peaks of expression around P6 (Figs. 7, 9,16 ), and subsequently also declined to adult levels (one-half and one-sixth of the respective peak expression; Figs. 11, 13, 16; Table 2). In contrast, cortical expression of the $\alpha_{1}$ and $\alpha_{4}$ genes increased (Figs. 1-5), especially after birth (Figs. 7, 9, 16), reaching levels at or slightly above adult by P12 (fivefold increase for $\alpha_{1}$ mRNA; Figs. 11, 13, 16; Table 2). Beginning at low degrees of expression at E17 (Fig. 4), the $\beta$ subunit mRNAs increased at different rates $\left(\beta_{3}>\beta_{2}>\beta_{1}\right)$, each reaching a peak in expression ( $\beta_{1}$ and $\beta_{2}$ at P12, $\beta_{3}$ at E19-P12; Figs. $\left.6-14,16\right)$. Transcripts for $\gamma_{1}$ and $\gamma_{2}$ were detected only at a very low level at E14 (Fig. 2). Thereafter, whereas cortical $\gamma_{1}$ mRNA expression showed a slight peak at $\mathrm{P} 0, \gamma_{2}$ mRNA reached a moderate level by birth, which continued into maturity (Figs. 4-14, 16). Cortical expression of $\gamma_{3}$ and $\delta$ mRNAs appeared around P0 and peaked at P6 and P12, respectively (Figs. 8-14, Table 2).

Each subunit transcript, besides exhibiting its own temporal pattern, also showed regional specificities of expression within the cortex. At E14, the cortex consists of a primordial plexiform layer that is split before E17 by the cortical plate of postmitotic neuroblasts (Jacobson, 1978; Miller, 1988). At E17 and E19, the $\alpha_{1}, \alpha_{2}, \alpha_{5}, \beta_{2}$, and $\beta_{3}$ mRNAs were most abundant in the outer cortical layer (layer I), the $\alpha_{3}$ and $\gamma_{2}$ transcripts were found in both outer and inner (subplate) layers, and the $\alpha_{2}, \alpha_{4}, \beta_{1}$, and $\gamma_{1}$ mRNAs were mainly located in the lower intermediate or ventricular zones (Figs. 3-6). No subunit transcript appeared to be expressed in the cortical plate. Stratification of cortical neurons (layers I-VI) is established by P6 (Jacobson, 1978; Miller, 1988 ) and the laminated patterns of transcript expression at this age were mostly continued into adulthood (see also Wisden et al., 1992). The $\alpha_{2}, \alpha_{4}$, and $\delta \mathrm{mRNAs}$ were found principally in outer layers, while $\alpha_{3}$ mRNA expression became restricted to more deeper regions. The $\gamma_{1}$ and $\gamma_{3}$ mRNAs were expressed almost homogeneously, whereas the $\alpha_{1}$, the three $\beta$, and the $\gamma_{2}$ transcripts were detected mainly in superficial and deep cortical layers (Figs. 9-12). In contrast, $\alpha_{5}$ mRNA was predominantly found in middle layers until P12, but in deep cortical layers in the adult (Figs. 7-13). In the postnatal entorhinal cortex, expression of all subunit mRNAs, except that of $\alpha_{3}$ and $\delta$, was higher than in neighboring cortex (e.g., Figs. 9-12). These patterns were maintained into adulthood, despite changes in absolute abundance.

\section{Hippocampus and septum}

Gene expression in the hippocampal formation was examined from the beginning of its formation (after E14; Stanfield and Cowan, 1988). In contrast to the changing predominance of $\mathrm{GABA}_{\mathrm{A}}$ subunit mRNAs in the cortex, the main transcripts found in the mature hippocampal CA regions $\left(\alpha_{2}, \alpha_{5}, \beta_{3}, \gamma_{2}\right)$ (Figs. 13, 14; Table 2) predominate from an early stage (E17; Figs. 3,4), soon after the neurons have finished migrating (Stan- 
Table 2. Schematic representation of the expression of the GABA $\mathrm{GAceptor} \alpha_{1}-\alpha_{6}, \beta_{1}-\beta_{3}, \gamma_{1}-\gamma_{3}$, and $\delta$ subunit mRNAs in selected entire regions of the embryonic and postnatal rat brain

\section{Telencephalon/Cortex}

E14 E17 E19 P0 P6 P12 Adult

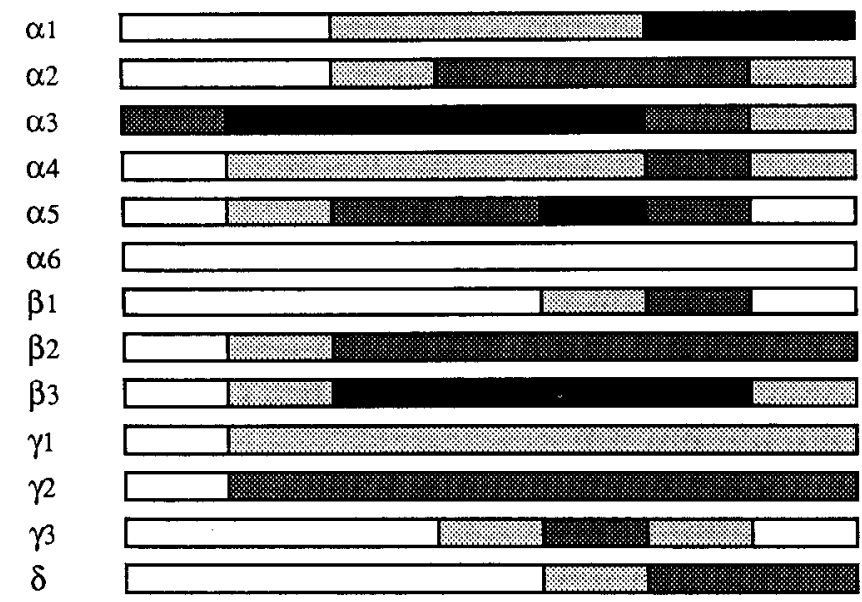

\section{Hippocampus}

\section{E14 E17 E19 P0 P6 P12 Adult}

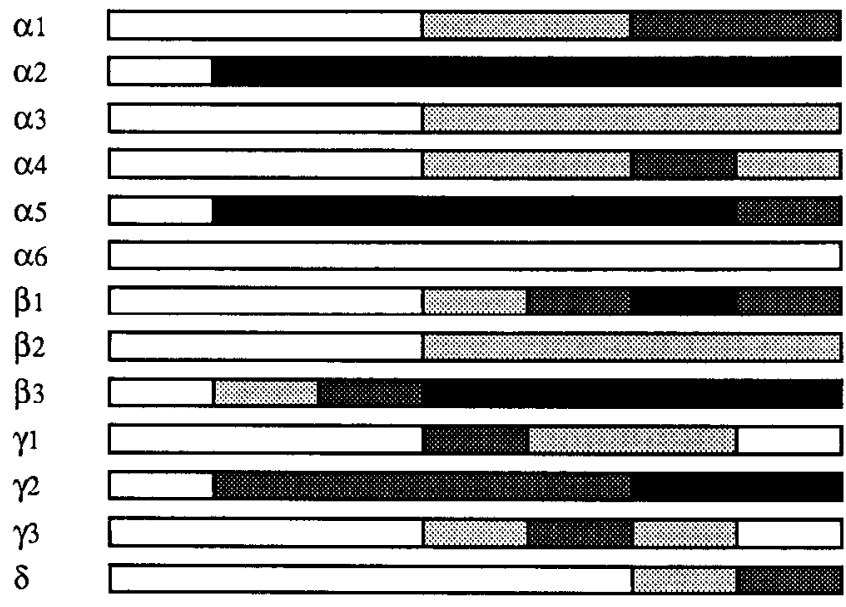

Diencephalon/Thalamus

\section{E14 E17 E19 P0 P6 P12 Adult}

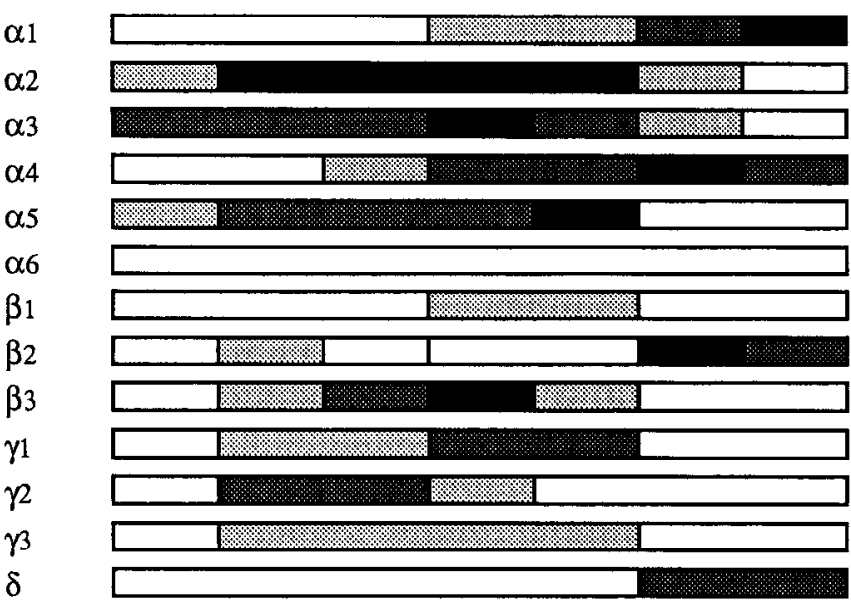

\section{Cerebellum}

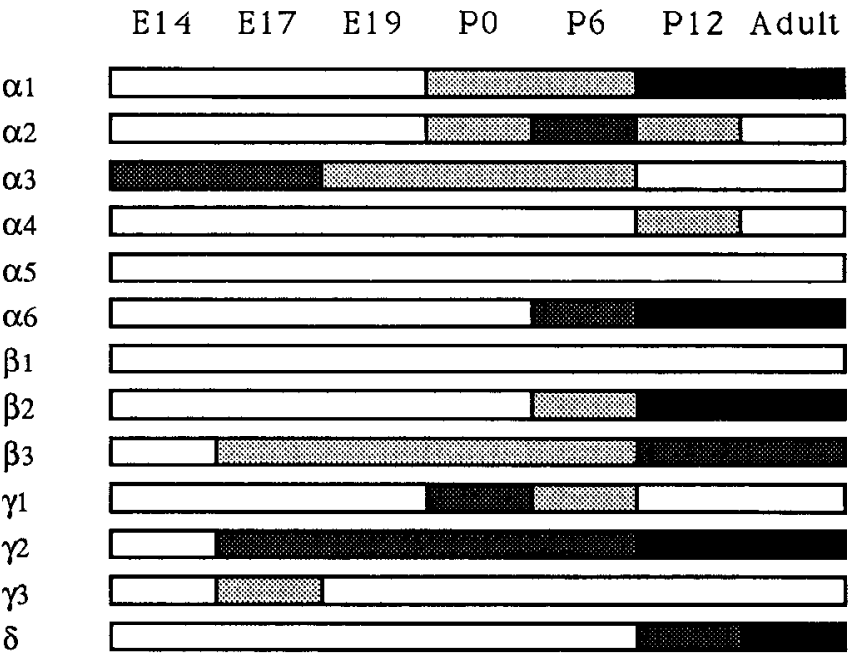

Black, strong signal; dark gray, moderate signal; light gray, weak signal; white, very weak or undetectable signal.

field and Cowan, 1988). In the dentate gyrus, a structure formed mainly postnatally (Stanfield and Cowan, 1988), adult expression patterns are quickly established (Figs. 7-10). No subunit mRNA was detected in E14 hippocampus (Figs. 1, 2), but at E17 and thereafter, marked expression of $\alpha_{2}$ and $\alpha_{5}$ mRNAs was obvious throughout the hippocampus (Figs. 3-11, 16). The expression of both mRNAs declined slightly (by $25 \%$ ) after P12 in CA1 and CA3, and $\alpha_{5}$ mRNA was found at lower levels in adult dentate gyrus (Figs. 13, 16). Transcripts for $\beta_{3}$ and $\gamma_{2}$ were also detected at low levels in E17 hippocampus, and subsequently increased rapidly (Figs. 4,6 ), $\beta_{3}$ mRNA reaching a strong perinatal expression (150\% of adult; Figs. 6, 8, 16). Expression of both transcripts resolved to moderate expression (Figs. 10-14, 16; Table 2). All other subunit transcripts were detectable only in postnatal hippocampus. Temporal expression patterns included a continuous low expression $\left(\beta_{2}\right)$, a gradual increase to adult levels $(\delta)$, a decrease after P6 $\left(\gamma_{1}\right)$, or a peak around P6 $\left(\gamma_{3}\right)$ or P12 $\left(\alpha_{3}, \alpha_{4}, \beta_{1}, \gamma_{3}\right.$; Figs. 7-14, 16; Table 2). Expression of $\alpha_{1}$ mRNA also peaked at P12, being 12 times that at E19 and a third more than adult, as assessed by optical density measurement (Fig. 16).

Mature spatial mRNA patterns in the hippocampal pyramidal cells and dentate gyrus granule cells were established soon after birth with homogeneous expression of $\alpha_{1}, \alpha_{2}, \beta_{1}, \beta_{2}, \beta_{3}, \gamma_{1}, \gamma_{2}$, and $\gamma_{3}$ transcripts, concentration of $\alpha_{3}$ and $\alpha_{5}$ mRNAs in CA3, and concentration of $\alpha_{4}$ and $\delta$ mRNAs in dentate gyrus (e.g., Figs. 9-14; see also Wisden et al., 1992). Strong expression of $\alpha_{2}, \alpha_{5}, \beta_{2}, \beta_{3}$, and $\gamma_{1}$ transcripts was noted in the early postnatal subiculum (Figs. 7-10), which in adulthood was replaced by lower expression of $\alpha_{1}, \alpha_{2}, \beta_{2}, \beta_{3}$, and $\gamma_{2}$ mRNAs (Figs. 11-14). 

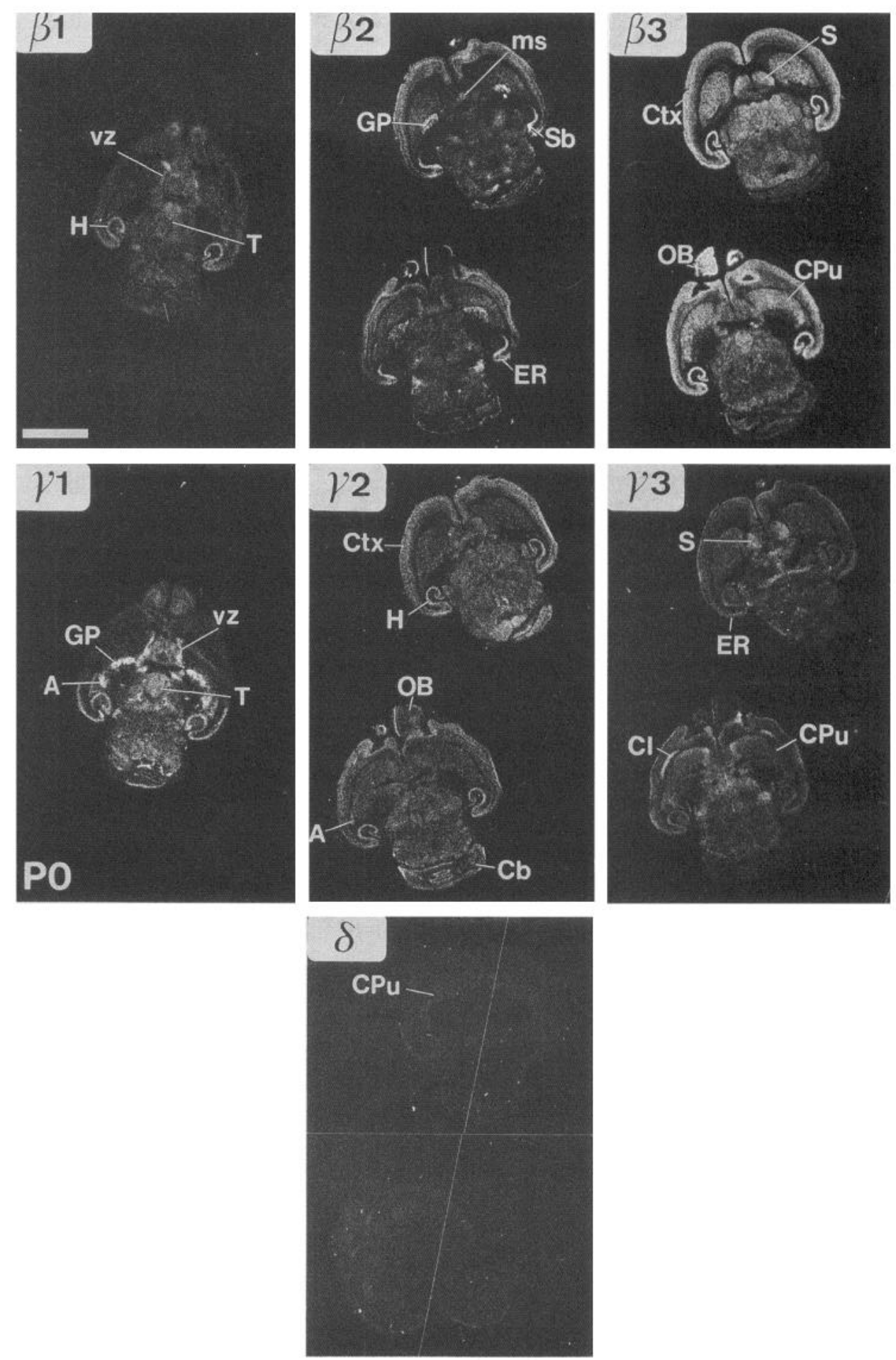

Figure 8. X-ray film autoradiographs illustrating distribution of $\mathrm{GABA}_{\mathrm{A}}$ receptor $\beta_{1}-\beta_{3}, \gamma_{1}-\gamma_{3}$, and $\delta$ mRNAs in horizontal sections of $\mathrm{P} 0$ rat brain. See Appendix for abbreviations. Scale bar, $4 \mathrm{~mm}$.

In addition, $\alpha_{1}, \alpha_{2}, \alpha_{4}, \beta_{2}, \beta_{3}$, and $\gamma_{2}$ mRNAs were detected postnatally in hippocampal interneurons, on examination of sections dipped in photographic emulsion (data not shown).

In the postnatal lateral septum, $\alpha_{2}$ mRNA was expressed strongly at all ages, while expression of $\alpha_{3}$ and $\gamma_{1}$ mRNAs declined from moderate neonatal levels to low adult levels (Figs. 7-14). Expression of other subunit transcripts declined gradually from moderate $\left(\alpha_{5}, \beta_{3}, \gamma_{3}\right)$ and low $\left(\beta_{1}, \gamma_{2}\right)$ levels at P0 (Figs. 7, $8)$ to very low levels in the adult (Figs. 9-14). In contrast, in the postnatal medial septum the $\beta_{2}$ and $\gamma_{2}$ transcripts were mod- erately expressed, and $\alpha_{1}$ mRNA increased as $\alpha_{2}$ and $\alpha_{3}$ mRNAs declined (Figs. 7-14).

\section{Olfactory bulb}

Subunit mRNAs expressed by each particular cell type of the olfactory bulb were similar at adult (see also Laurie et al., 1992) and perinatal stages, as assessed on emulsion-dipped sections. Thus, $\beta$, mRNA was found only in mitral cells; $\alpha$, mRNA in mitral and tufted cells; $\beta_{2}$ mRNA in mitral, tufted, and periglomerular cells; $\alpha_{2}, \alpha_{5}, \gamma_{1}, \gamma_{3}$, and $\delta$ mRNAs in postmigratory 

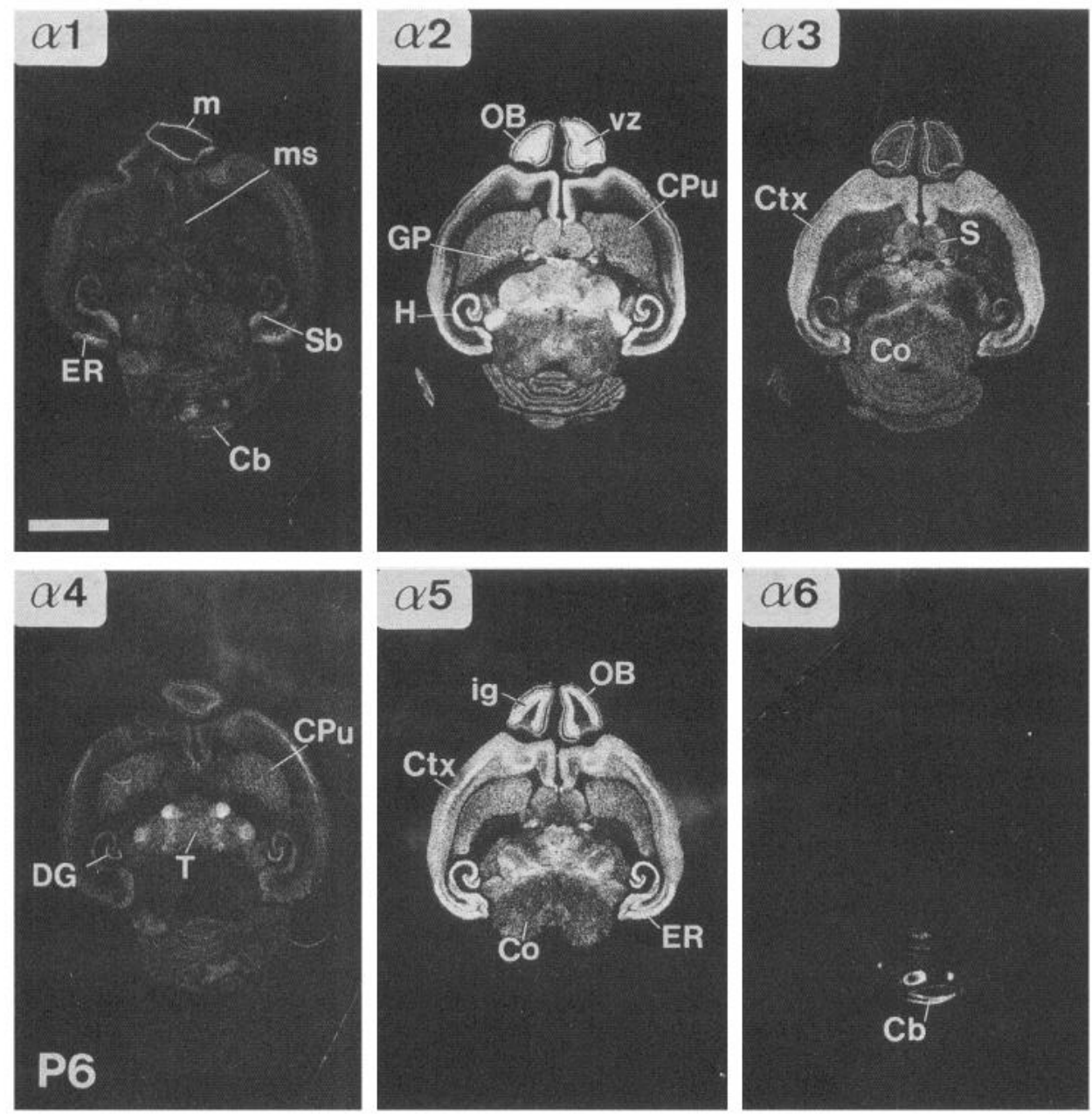

Figure 9. X-ray film autoradiographs illustrating distribution of $\mathrm{GABA}_{\mathrm{A}}$ receptor $\alpha_{1}-\alpha_{6}$ mRNAs in horizontal sections of P6 rat brain. See Appendix for abbreviations. Scale bar, $4 \mathrm{~mm}$. granule and periglomerular cells; and $\alpha_{3}, \alpha_{4}, \beta_{3}$, and $\gamma_{2}$ transcripts in all these cell types (e.g., Figs. 9, 10). At perinatal ages, $\alpha_{2}, \alpha_{5}$, and $\gamma_{1}$ mRNAs were also strongly expressed in mitral cells (Figs. $5-10,15)$. In addition, the $\alpha_{2}$ and $\gamma_{1}$ transcripts were present in immature, premigratory granule cells in the ventricular zone (e.g., Figs. 9, 10). The subunit mRNAs most prominently expressed throughout development were those of $\alpha_{2}, \alpha_{5}$, and $\beta_{3}$, which attained perinatal peaks of strong expression (Figs. 512). Some others, which were much more weakly expressed, also peaked around E19 $\left(\gamma_{1}\right)$, E19-P6 $\left(\alpha_{3}\right)$, or P6-P12 $\left(\gamma_{3}\right)$. In contrast, yet other mRNAs, detectable at E19 (Figs. 5, 6), rapidly reached persistently strong $\left(\alpha_{1}, \beta_{2}, \gamma_{2}\right)$, moderate $\left(\beta_{1}\right)$, or low $\left(\alpha_{4}\right)$ levels (Figs. 7-14). The $\delta$ transcript was detectable at P6 and reached moderate expression by P12 (Figs. 10-14).

\section{Thalamus}

In the diencephalon of developing rats, marked changes occurred in transcript predominance (summarized in Table 2). Of the $\alpha$ subunits, $\alpha_{2}, \alpha_{3}$, and to a lesser extent $\alpha_{3}$ were the major mRNAs in the embryonic diencephalon (Figs. 1, 3, 5; Table 2). Expression of $\alpha_{3}$ mRNA peaked slightly at P0 (Fig. 7), while marked $\alpha_{2}$ and $\alpha_{5}$ mRNA expression continued until P6 (Figs. $9,16)$, after which all three transcripts declined dramatically before P1 2 and were only faintly detectable in the midline adult thalamus (Figs. 11, 13; Table 2). Expression of the $\alpha_{2}$ and $\alpha_{\text {s }}$ mRNAs in whole adult thalamus was approximately $15 \%$ and $5 \%$, respectively, of P6 levels (Fig. 16). Expression of $\beta_{3}, \gamma_{1}, \gamma_{2}$, and $\gamma_{3}$ mRNAs underwent similar temporal patterns, albeit at a generally lower intensity (Figs. 2-14, 16; Table 2). Expression of $\beta_{1}$ mRNA remained at a continuously low level (Figs. 4-14). Diencephalic $\alpha_{4}$ mRNA gradually increased from low embryonic levels (Figs. 3, 5), reaching a strong peak at P12 (Figs. 713 ), while the slowly increasing production of $\alpha_{1}, \beta_{2}$, and $\delta$ mRNAs (Figs. 1-10) accelerated after P6 to adult levels by P12 (Figs. 11-14, 16; Table 2). The variety of expression patterns in the various thalamic nuclei of neonates and adults was remarkable (see also Wisden et al., 1992). In brief, throughout development, $\alpha_{3}, \beta_{1}, \gamma_{1}$, and $\gamma_{3}$ transcripts tended to be expressed in midline thalamic nuclei (although $\alpha_{3}$ and $\gamma_{3}$ mRNAs were also found in reticular thalamus and medial geniculate, respectively), as did $\alpha_{2}, \alpha_{5}$, and $\beta_{3}$ mRNAs before and after their peaks of expression (Figs. 7-14). The $\alpha_{2}$ and $\alpha_{5}$ mRNAs at their maxima and the $\alpha_{1}, \alpha_{4}, \beta_{2}$, and $\gamma_{2}$ mRNAs were found throughout the thalamus, while $\delta$ mRNA was located in lateral thalamic nuclei (Figs. 714).

\section{Striatum}

\section{Caudate putamen}

Transcript expression in the embryonic striatum and postnatal caudate followed a temporal pattern similar to that described for the thalamus. Expression of $\alpha_{2}, \alpha_{3}, \alpha_{5}$, and $\beta_{3}$ mRNAs gradually increased from low levels at E14 (Figs. 1-8); peaked in caudate prior to birth $\left(\alpha_{3}\right.$; Figs. 5-8), at P0 $\left(\alpha_{2}, \beta_{3}\right)$, or at P6 $\left(\alpha_{5}\right.$; Figs. 7-10); and subsequently decreased to moderate $\left(\alpha_{2}\right)$ or very 

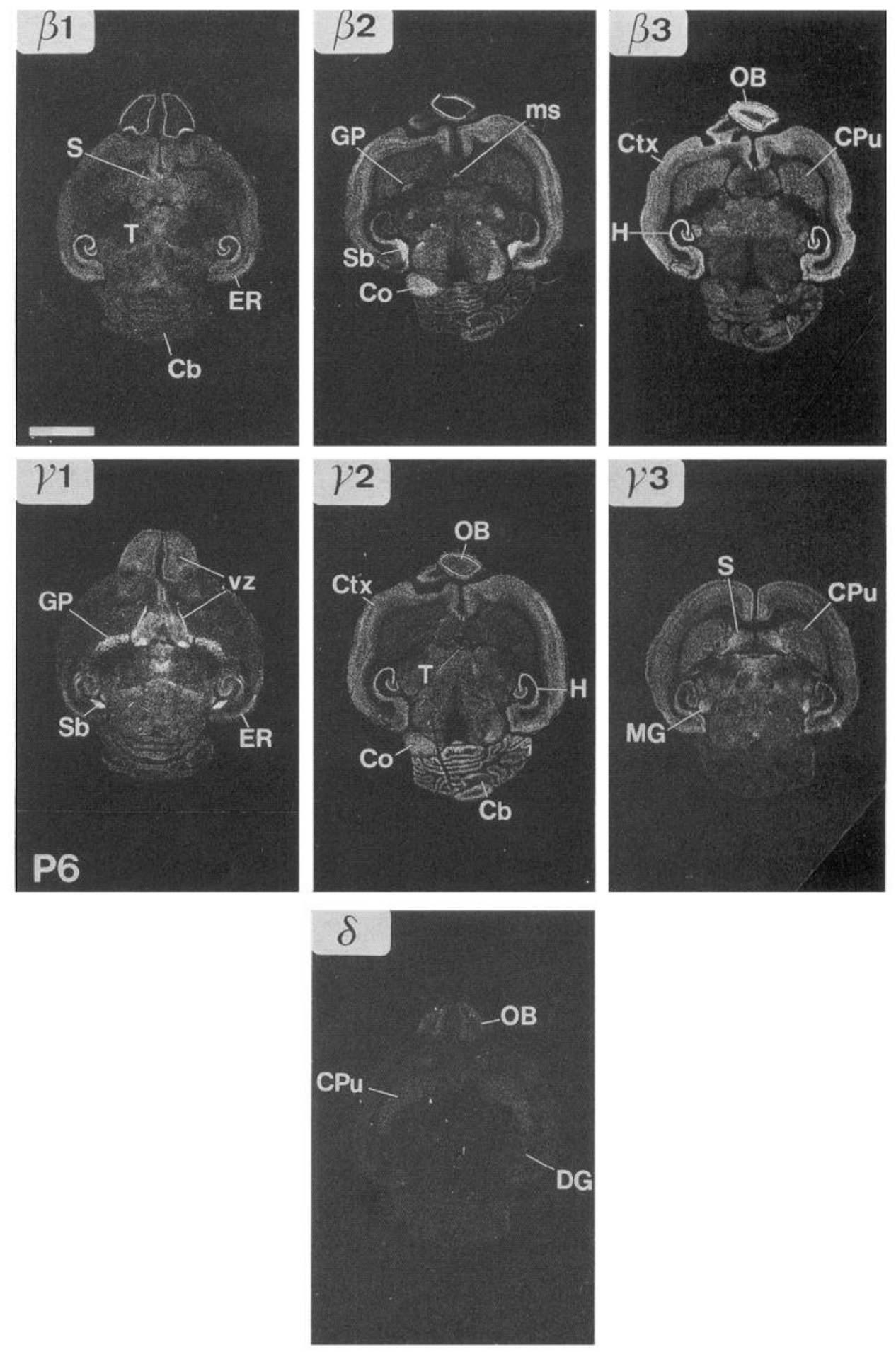

Figure 10. X-ray film autoradiographs illustrating distribution of GA$\mathrm{BA}_{\wedge}$ receptor $\beta_{1}-\beta_{3}, \gamma_{1}-\gamma_{3}$, and $\delta$ mRNAs in horizontal sections of $\mathrm{P} 6$ rat brain. See Appendix for abbreviations. Scale bar, $4 \mathrm{~mm}$.

low $\left(\alpha_{3}, \alpha_{5}, \beta_{3}\right)$ expression in the adult caudate (Figs. 11-14). Expression of $\alpha_{1}$ and $\beta_{2}$ mRNAs was detected at all stages of postnatal caudate at a low level (Figs. 7-14). Production of $\alpha_{4}$ mRNA began in caudate around E19 (Fig. 5) and gradually increased until P12 (Figs. 7-11) before declining slightly to moderate adult levels (Fig. 13). The $\gamma_{1}, \gamma_{2}$, and $\gamma_{3}$ mRNAs were expressed only to a low degree in embryonic, postnatal, and adult caudate (Figs. 2-14). Expression of the $\delta$ gene was just detectable in neonatal caudate (Fig. 8) and gradually increased to a moderate adult level (Figs. 10, 12, 14).

\section{Globus pallidus}

The globus pallidus exhibited an expression profile that often contrasted strongly with that in caudate. No $\alpha_{4}, \alpha_{5}$, or $\delta$ transcripts were detected in the globus pallidus at any age. Expression levels in globus pallidus declined from pronounced $\left(\alpha_{2}, \gamma_{1}\right)$ or low $\left(\alpha_{3}, \beta_{1}, \beta_{3}, \gamma_{2}, \gamma_{3}\right)$ expression at P0 down to low $\left(\gamma_{1}\right)$ or very low levels in P12 and adult (Figs. 7-14). In contrast, postnatal expression of the $\alpha_{1}$ gene gradually increased to strong in P12 and adult globus pallidus (Figs. 7-13), while $\beta_{2}$ mRNA 



Figure 11. X-ray film autoradiographs illustrating distribution of $\mathrm{GA}$ $\mathrm{BA}_{\mathrm{A}}$ receptor $\alpha_{1}-\alpha_{6}$ mRNAs in horizontal sections of $\mathrm{P} 12$ rat brain. See Appendix for abbreviations. Scale bar, $4 \mathrm{~mm}$. remained continuously strong (Figs. 8-14). In young postnatal brain (P0-P12), $\beta_{1}$ and $\gamma_{1}$ mRNAs were also observed in the caudate ventricular zone (Figs. 8-12).

\section{Colliculi}

The $\alpha_{2}, \alpha_{3}$, and $\alpha_{5}$ mRNAs were detected at moderate or low levels in the E14 mesencephalon (Fig. 1) and remained at the same levels, or increased $\left(\alpha_{2}\right)$, until E19 (Figs. 3, 5). After birth, expression of these gradually declined to low $\left(\alpha_{2}, \alpha_{3}\right)$ or undetectable $\left(\alpha_{5}\right)$ levels (Figs. 9-13). Expression of $\beta_{3}$ and $\gamma_{1}$ mRNAs followed a similar temporal profile (Figs. 2-14), while $\beta_{1}$ and $\gamma_{3}$ mRNAs remained very low throughout development (Figs. $2-14)$. In contrast, other mRNAs exhibited low $\left(\beta_{2}, \gamma_{2}\right)$ or undetectable $\left(\alpha_{1}\right)$ levels at E14 (Figs. 1-6) and then gradually increased (Figs. 3-6), especially in the inferior colliculi, to adult levels by P12 (Figs. 9-14). Transcripts for $\alpha_{4}$ and $\delta$ were not detectable in mesencephalon (Figs. 1-14).

\section{Cerebellum}

In the rat cerebellum, most $\mathrm{GABA}_{\mathrm{A}}$ receptor mRNA expression was restricted to the period of postnatal development (Table 2). Prior to birth, homogeneous, low cerebellar expression of $\alpha_{3}, \beta_{3}$, and $\gamma_{2}$ transcripts was observed (Figs. 1-6). At P0, hybridization over the multilayered Purkinje cells (Jacobson, 1978) was observed with the $\alpha_{1}, \beta_{2}, \beta_{3}$, and $\gamma_{2}$ probes (Figs. 7, 8, 15). By P6, the Purkinje cells had resolved into a monolayer, with strong signals over each cell. This picture continued into adulthood
(Figs. 9-15; see also Laurie et al., 1992). Transcripts for $\alpha_{2}, \alpha_{3}$, $\beta_{3}, \gamma_{1}$, and $\gamma_{2}$ were observed in the external granule cell layer from the thick layer at P0 to the very thin layer at P12, and in granule cells migrating through the molecular layer to the internal granule cell layer. By P6, all subunit mRNAs, except those for $\alpha_{5}$ and $\delta$, could be detected at low levels in postmigratory granule cells (Figs. 9, 10). After P6, some transcripts showed small changes of expression in postmigratory granule cells: a decline $\left(\alpha_{2}, \alpha_{3}, \beta_{1}, \gamma_{1}, \gamma_{3}\right)$ or a slight peak at P12 $\left(\alpha_{4}\right.$; Figs. $11-$ 14). In contrast, others $\left(\alpha_{1}, \alpha_{6}, \beta_{2}, \beta_{3}, \gamma_{2}, \delta\right)$ exhibited a very pronounced increase between P6 and P12 to adult levels of expression (Figs. 11-14). Labeling of stellate/basket cells in the molecular layer by the probes for $\alpha_{1}, \beta_{2}$, and $\gamma_{2}$ mRNAs was observed only in the adult cerebellum. A "halo" of hybridization for the $\alpha_{2}$ and $\gamma_{1}$ mRNAs in the molecular layer at its border with the granule cell layer, consistent with labeling of putative Bergmann glia, was apparent at and after P12 (Figs. 11-14; see also Laurie et al., 1992).

\section{Spinal cord}

As sections were not taken through postnatal spinal cord, only embryonic $\mathrm{GABA}_{\mathrm{A}}$ receptor $\mathrm{mRNA}$ expression can be described here. Transcripts for $\alpha_{1}$ and $\delta$ were not detected (Figs. 1-6). All other subunit mRNAs remained at continuously strong $\left(\alpha_{2}, \alpha_{3}\right.$, $\left.\alpha_{5}, \beta_{3}, \gamma_{1}, \gamma_{2}\right)$, low $\left(\beta_{1}\right)$, or very low levels $\left(\alpha_{4}, \beta_{2}, \gamma_{3}\right.$; Figs. 1-6). At E14, expression of $\alpha_{4}, \beta_{1}$, and $\gamma_{1}$ mRNAs appeared to be restricted to the ventricular germinal zone surrounding the cen- 

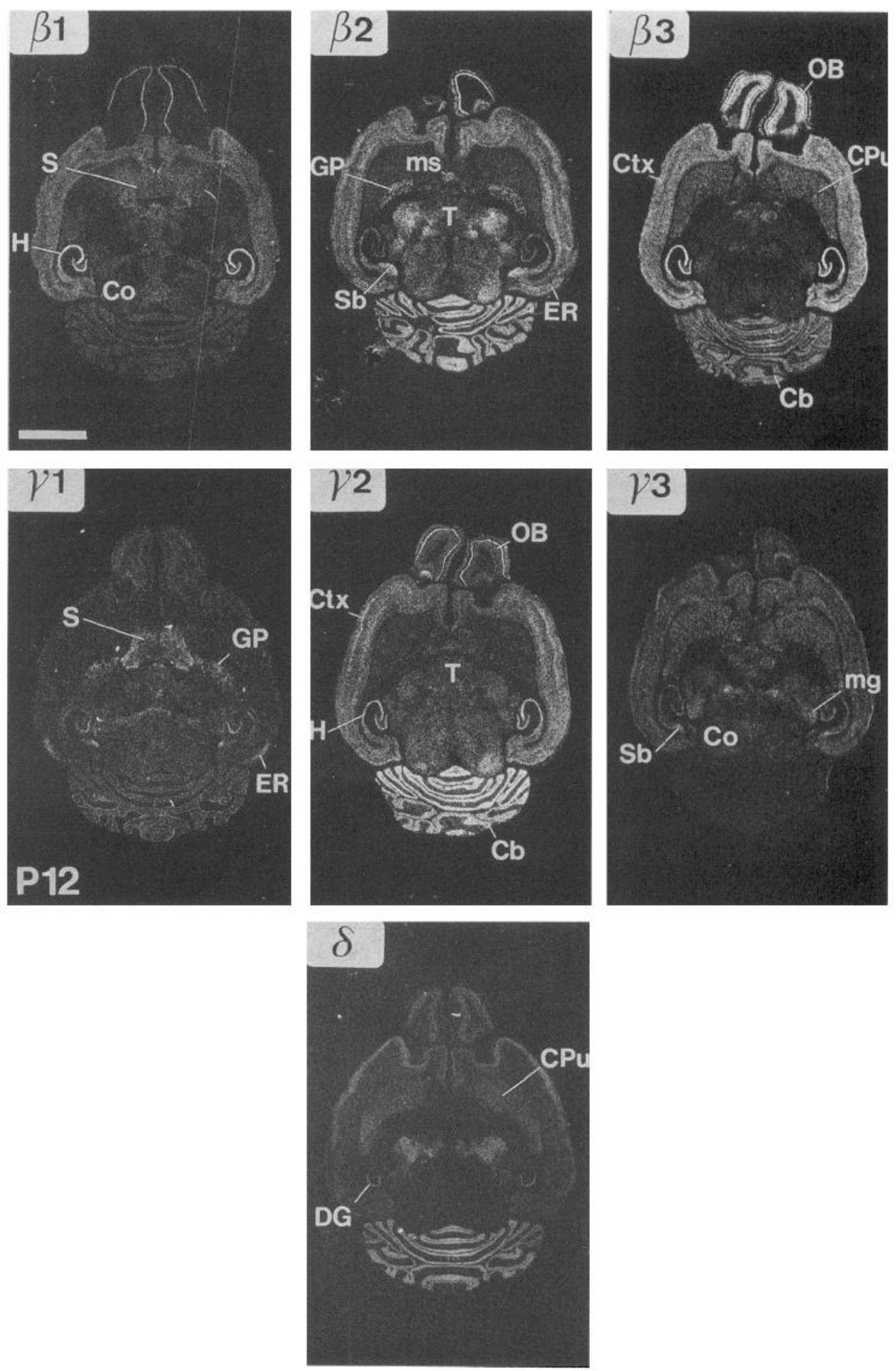

expressed in dorsal root ganglia at all embryonic ages (Figs. 1, 2), and moderate signals for $\alpha_{2}, \alpha_{3}, \beta_{3}$, and $\gamma_{2}$ transcripts were detected in the E17 trigeminal ganglion (Fig. 3). The $\gamma_{3}$ mRNA was strongly expressed in embryonic (E14-E19) intestine (Fig. 2 ), although the cellular resolution of this signal could not be determined.

\section{Discussion}

In this study, different ontogenic progressions in expression have been revealed for each of $13 \mathrm{GABA}_{\mathrm{A}}$ receptor subunit genes (see

Table 2 for summary). The results suggest that the adult subunit
In the course of this study, specific signals for certain subun mRNAs were also found in peripheral embryonic nervous tissues. The $\alpha_{2}, \alpha_{3}, \beta_{3}, \gamma_{1}, \gamma_{2}$, and $\gamma_{3}$ transcripts were moderately
Figure 12. X-ray film autoradiographs illustrating distribution of GAin horizontal sections of $\mathrm{P} 12$ rat brain. bar, $4 \mathrm{~mm}$. bryonic development (e.g., $\alpha_{5}, \beta_{1}, \gamma_{1}$ ), while others showed a homogeneous distribution $\left(\alpha_{3}, \beta_{3}, \gamma_{2}\right.$; Figs. 1-6). The $\gamma_{3}$ mRNA expression in E17 and E19 spinal cord was concentrated primarily in the most dorsal region (Figs. 4, 6).

\section{Peripheral localization}



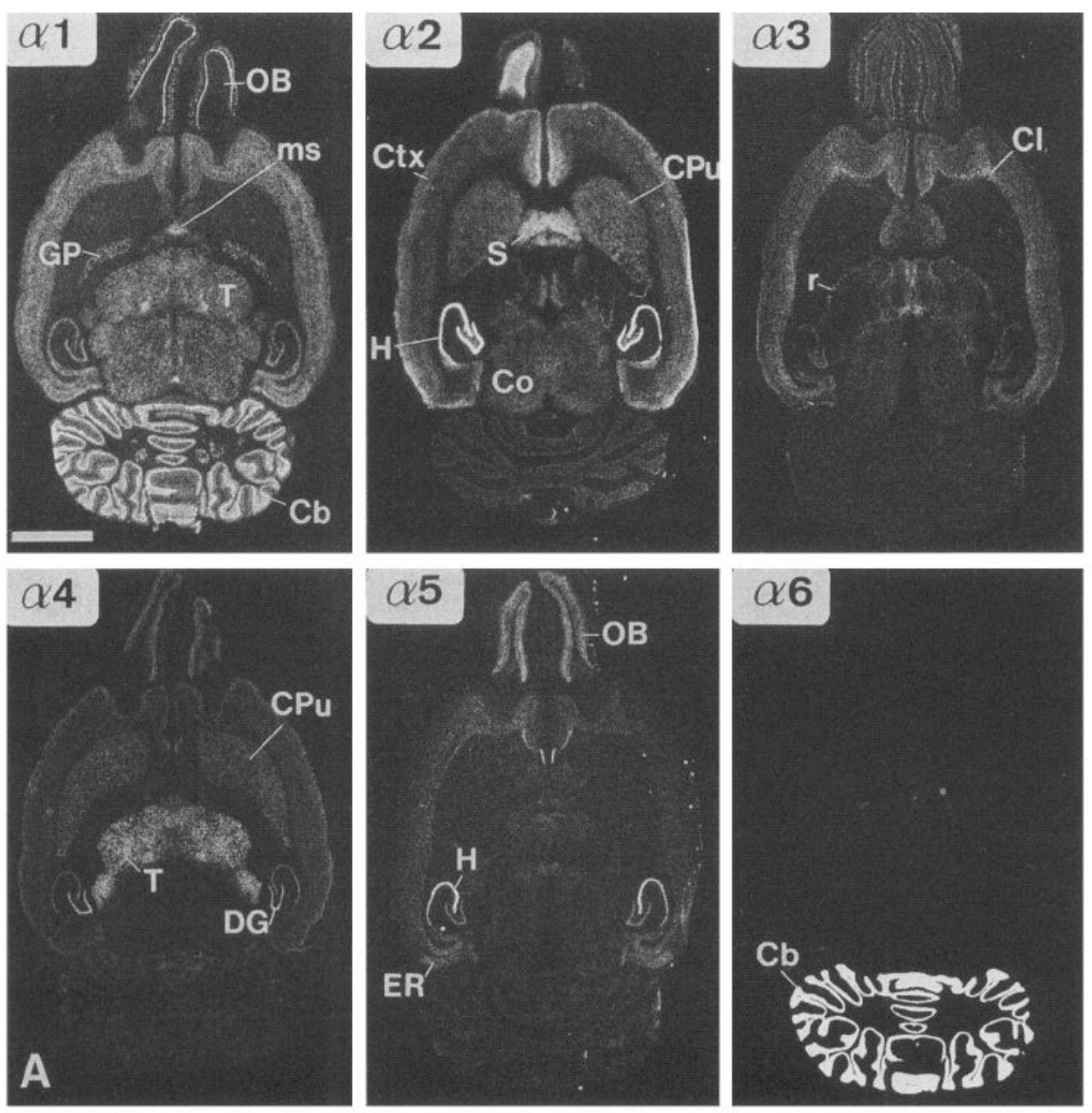

Figure 13. X-ray film autoradiographs illustrating distribution of GA$\mathrm{BA}_{\mathrm{A}}$ receptor $\alpha_{1}-\alpha_{6}$ mRNAs in horizontal sections of adult rat brain. See Appendix for abbreviations. Scale bar, $4 \mathrm{~mm}$. composition of the $\mathrm{GABA}_{\mathrm{A}}$ receptor in certain brain regions (e.g., cortex) differs substantially from that in the embryo and neonate and that some receptor populations persist throughout development (e.g., in hippocampus) while others proceed postnatally almost directly to an adult form (e.g., in cerebellum; summarized in Tables 1,2). One of the most striking features of $\mathrm{GABA}_{\mathrm{A}}$ subunit expression during brain development is the marked, widespread expression of the $\alpha_{2}$ and $\alpha_{5}$ mRNAs, which reaches an early peak and then declines (Figs. 9, 16), while in contrast, $\alpha_{1}$ mRNA expression increases (Figs. 9, 11, 13, 16). Expression of $\beta_{1}$ mRNA mimics that of the $\alpha_{2}$ and $\alpha_{5}$ transcripts, albeit at a much lower intensity. Such developmental changes of $\alpha_{1}, \alpha_{2}, \alpha_{5}$, and $\beta_{1}$ mRNA expression agree with Northern analysis of whole rat brain (Garrett et al., 1990; MacLennan et al., 1991). Note that the sequence termed $\alpha_{5}$ by us is referred to as $\alpha_{4}$ by MacLennan et al. (1991; see Materials and Methods). The expression patterns revealed in this study provide a possible molecular explanation for earlier observations (see introductory remarks) concerning global and regional changes in the pharmacological properties of $\mathrm{GABA}_{\mathrm{A}}$ receptors during development.

Regional changes in expression during development as detected by film autoradiography probably reflect both changes in the expression repertoire of neurons, and alterations in neuronal density. The developing vertebrate brain produces an excess of neurons, many of which are selectively eliminated in early development (Oppenheim, 1991). A point yet to be examined is whether the widespread loss of early-type gene expression (e.g., $\alpha_{2}$ and $\alpha_{5}$ in cortex and thalamus) is due to changes of gene expression within neurons or to death of a population of cells specifically expressing these genes. The main period of developmental neuronal death, however, happens after mature synaptogenesis (Oppenheim, 1991), which in the rat cortex occurs principally in the third and fourth postnatal weeks (Aghajanian and Bloom, 1967). This may therefore argue against marked, selective destruction between $\mathrm{P} 6$ and $\mathrm{P} 12$ of neurons expressing the early $\mathrm{GABA}_{\mathrm{A}}$ gene profile.

With regard to regional expression, $\mathrm{GABA}_{\mathrm{A}}$ receptors of the developing cortex, hippocampus, and cerebellum have been most extensively studied by previous binding and electrophysiological experiments and will be discussed in some detail.

\section{Cortical receptors}

The pronounced cortical expression of $\alpha, \beta$, and $\gamma$ subunit genes by birth (Figs. 7, 8; Table 2) predicts the early formation of functional $\mathrm{GABA}_{\mathrm{A}}$ receptors. Paradoxically, although cortical $\mathrm{BZ}$ binding is already substantial at birth $(60 \%$ of adult; Candy and Martin, 1979; Lippa et al., 1981; Chisholm et al., 1983) and is coupled to $\mathrm{GABA}_{\mathrm{A}}$ receptors (Palacios et al., 1979; Eichinger and Sieghart, 1986; Kellogg and Pfleger, 1989), the number of rat cortical GABA and muscimol binding sites is low at birth ( $25 \%$ of adult) and increases only after P8 (Coyle and Enna, 1976; Vitorica et al., 1990). The appearance of most cortical $\mathrm{GABA}_{\mathrm{A}}$ binding coincides with the replacement of perinatal 

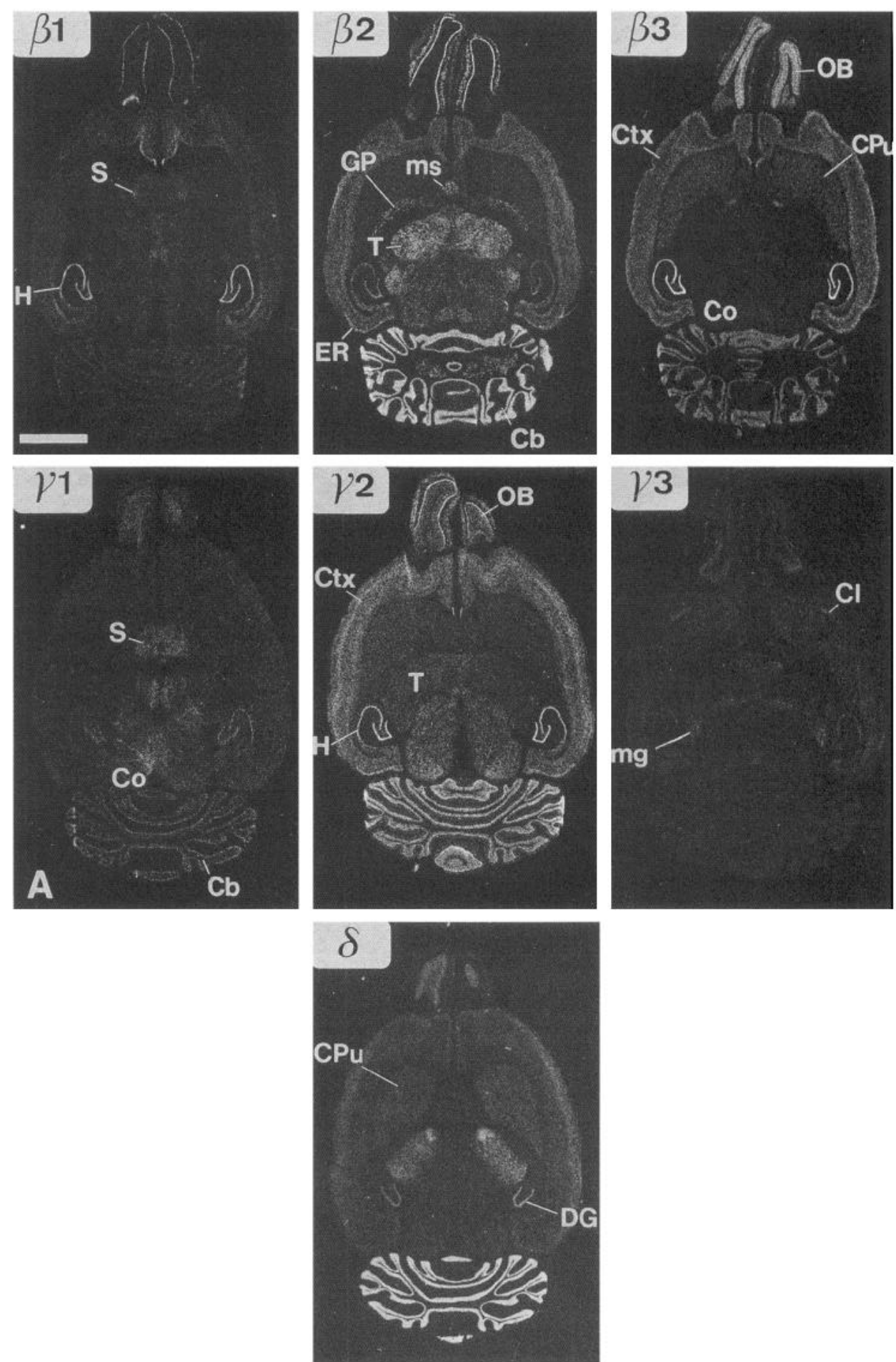

Figure 14. X-ray film autoradiographs illustrating distribution of GA$\mathrm{BA}_{\mathrm{A}}$ receptor $\beta_{1}-\beta_{3}, \gamma_{1}-\gamma_{3}$, and $\delta$ mRNAs in horizontal sections of adult rat brain. See Appendix for abbreviations. Scale bar, $4 \mathrm{~mm}$. transcripts (e.g., $\alpha_{2}, \alpha_{3}, \alpha_{5}, \beta_{3}$ ) with adult ones (e.g., $\alpha_{1}, \alpha_{4}, \beta_{2}, \delta$; Figs. 9-12, Table 2). The early subunit composition or posttranslational subunit modifications may impede marked GA$\mathrm{BA}_{\mathrm{A}}$ binding. In adult rat brain, such mismatches in the densities of $\mathrm{GABA}_{\mathrm{A}}$ and $\mathrm{BZ}$ binding sites occur in regions such as the cerebellum, thalamus, and hippocampus (Unnerstall et al., 1981; Olsen et al., 1990).

Recombinant $\mathrm{GABA}_{\mathrm{A}}$ receptors of the combination $\alpha_{1} \beta_{x} \gamma_{2}$ (where $x=1-3$ ) exhibit type I BZ binding, whereas $\alpha_{2} \beta_{x} \gamma_{2}$, $\alpha_{3} \beta_{x} \gamma_{2}$, and $\alpha_{5} \beta_{x} \gamma_{2}$ assemblies display type II BZ pharmacology (Pritchett et al., 1989a; Pritchett and Seeburg, 1990). Receptors of composition $\alpha_{5} \beta_{x} \gamma_{2}$ also exhibit very low affinity for the partial agonist zolpidem (Pritchett and Seeburg, 1990). GABA receptors exhibiting such pharmacologies are precipitated from brain homogenates by the appropriate $\alpha$ subunit antibodies (McKernan et al., 1991b). From their mRNA expression levels, the $\alpha_{2}, \alpha_{3}, \alpha_{5}, \beta_{1}, \beta_{2}, \beta_{3}, \gamma_{2}$, and $\gamma_{3}$ subunits are predicted to exist in perinatal cortical receptors, the composition depending on the 

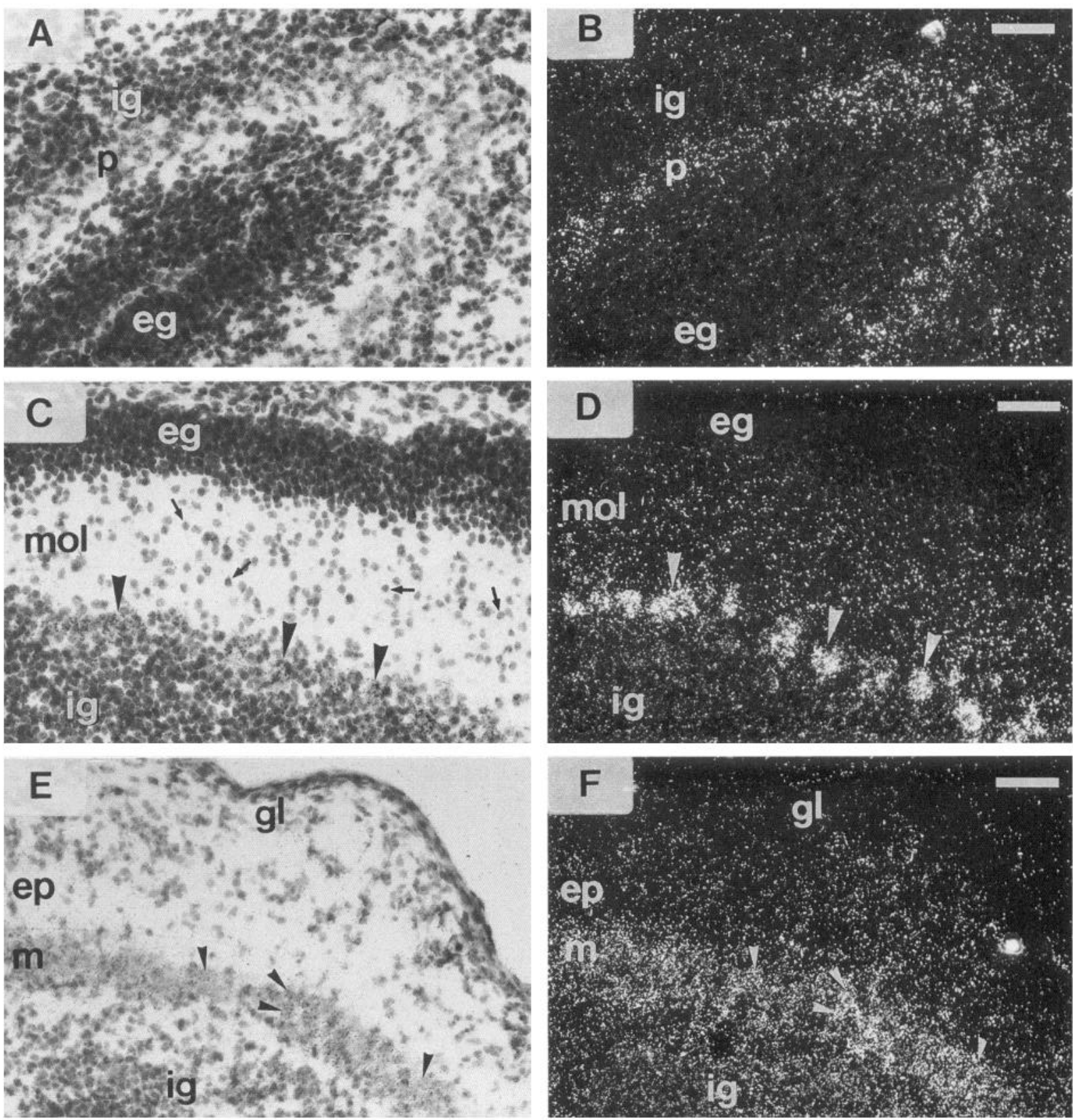

Figure 15. Microscopic resolution of hybridization in thionin-stained sections. Left column, bright-field optics; right column, corresponding darkfield optics. $A$ and $B, \alpha_{1}$ mRNA in P0 cerebellum; $C$ and $D, \alpha_{1}$ mRNA in P12 cerebellum; $E$ and $F, \alpha_{2}$ mRNA in P0 olfactory bulb. See Appendix for abbreviations. Arrows in $C$ and $D$, migrating granule cells. Arrowheads, in $C$ and $D$, purkinje cells; in $E$ and $F$, mitral cells. Scale bar, $50 \mu$ m.

cortical layer (e.g., $\alpha_{2} \beta_{3} \gamma_{2}, \alpha_{3} \beta_{2} \gamma_{3}, \alpha_{5} \beta_{1} \gamma_{2}$; Figs. 3-10). Later expression patterns indicate a majority of $\alpha_{1} \beta_{2} \gamma_{2}$ assemblies (Figs. 13, 14; see also Benke et al., 1991; Gambarana et al., 1991; Wisden et al., 1992). These expression changes are therefore consistent with (1) type II and type I BZ receptors predominating in neonatal and adult cortex, respectively (Lippa et al., 1981; Chisholm et al., 1983); (2) zolpidem having very low affinity for P6 rat brain homogenates (Sieghart and Schlerka, 1991); and (3) ${ }^{3} \mathrm{H}$-flunitrazepam photolabeling mainly three $\alpha$ subunit proteins $(55,59,62 \mathrm{kDa})$ in neonatal cortex, and mainly one (51 $\mathrm{kDa}$ ) in adult cortex (Eichinger and Sieghart, 1986; Sato and Neale, 1989; Fuchs et al., 1990; Vitorica et al., 1990).

\section{Hippocampal receptors}

Based on transcript levels, most perinatal hippocampal GABA $A_{A}$ receptors would be formed from a selection of $\alpha_{2}, \alpha_{5}, \beta_{1}, \beta_{3}, \gamma_{1}$, and $\gamma_{2}$ subunits, with fewer receptors containing $\alpha_{3}, \alpha_{4}$, and $\gamma_{3}$ subunits (Figs. 7-10, Table 2). By P12, all subunits except $\alpha_{6}$ could contribute to hippocampal $\mathrm{GABA}_{\mathrm{A}}$ receptors, although by this time $\gamma_{1}$ and $\gamma_{3}$ would have a minor contribution. The expression levels of each hippocampal transcript during development could explain both the dense BZ binding at birth and the continuous predominance of type II BZ receptors in the hippocampus (Chisholm et al., 1983; Sieghart and Schlerka, 




$\alpha 2$

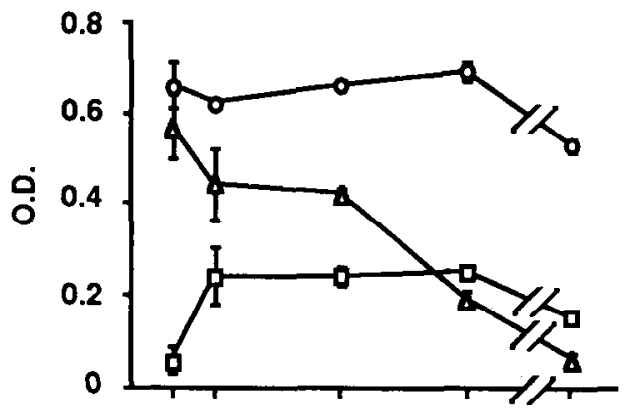

$\alpha 5$

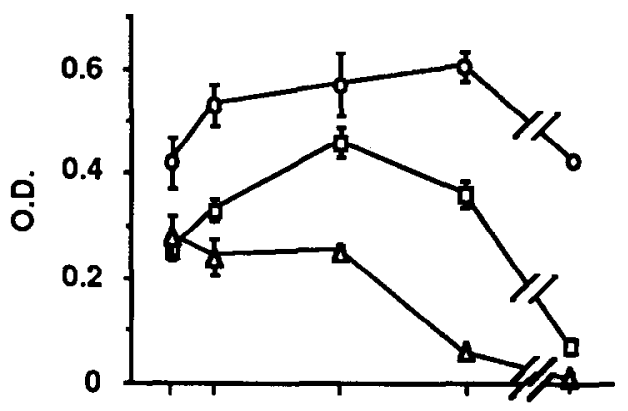

$\beta 3$

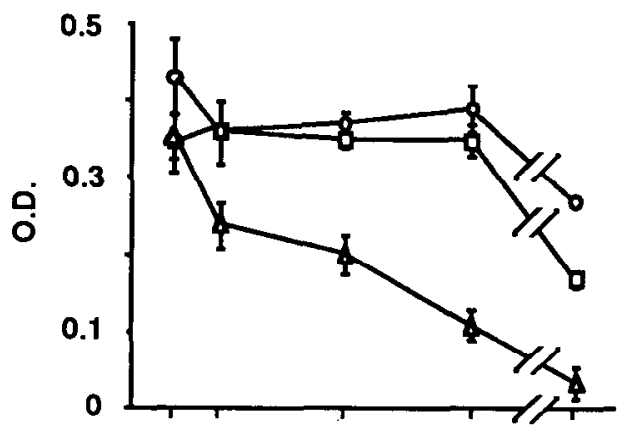

$\gamma 2$

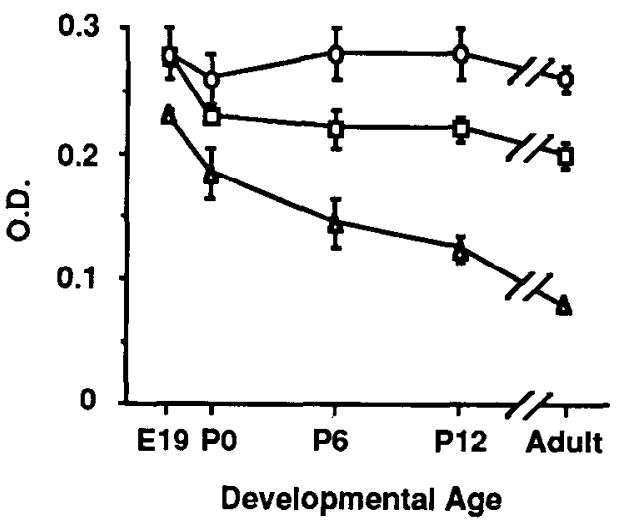

Figure 16. Developmental expression of $\alpha_{1}, \alpha_{2}, \alpha_{5}, \beta_{3}$, and $\gamma_{2}$ mRNAs, as representative mRNAs, in regions of rat brain as measured by optical densities $(O . D$.) of $\mathrm{x}$-ray film images. Data points represent means \pm SEM of values from three animals: squares, neocortex (all layers); circles,
1991). Diazepam-resistant Ro15-4513 binding and type I BZ binding (Turner et al., 1991; Wisden et al., 1991a) would be predicted to appear gradually with increasing age, while pharmacology contributed by the $\gamma_{1}$ subunit (Puia et al., 1991) should diminish.

\section{Cerebellar receptors}

The results described for $\alpha_{1}, \beta_{1}, \beta_{2}, \beta_{3}$, and $\gamma_{2}$ mRNA expression agree with similar studies on the postnatal rodent cerebellum (Gambarana ct al., 1990, 1991; Zdilar ct al., 1991; Zhang et al., 1991). Consistent with our results, functional GABA $A$ receptors are present on Purkinje cells at birth (Woodward et al., 1971), and cerebellar $\alpha_{1}$-like immunoreactivity on Western blots increases postnatally (McKernan et al., 1991a).

The increasing postnatal expression of $\mathrm{GABA}_{\mathrm{A}}$ transcripts in both Purkinje and postmigratory granule cells $\left(\alpha_{1}, \beta_{2}, \beta_{3}, \gamma_{2}, \delta\right)$ is paralleled by increases in $\mathrm{GABA}_{\mathrm{A}}$ and type $\mathrm{I} \mathrm{BZ}$ binding after P8 (Coyle and Enna, 1976; Candy and Martin, 1979; Palacios and Kuhar, 1982; Chisholm et al., 1983; Zdilar et al., 1991). An acceleration of BZ binding mainly in the molecular layer between P14 and P28 is probably due to the coincident development of the Purkinje cell dendritic tree (Jacobson, 1978) and extensive production of receptors containing $\alpha_{1}, \beta_{2} / \beta_{3}$, and $\gamma_{2}$ subunits. The transient production by postmigratory granule cells of almost all GABA $A_{\mathrm{A}}$ transcripts (e.g., $\alpha_{2} \beta \gamma_{2}, \alpha_{3} \beta \gamma_{2}$ assemblies) cxplains the initial heterogeneity of cerebellar BZ binding sites and BZ-photolabeled proteins (Chisholm et al., 1983; Sieghart, 1986). Worthy of note is the absolute restriction of the $\alpha_{6}$ mRNA to postmigratory granule cells (Figs. 9-13), indicating a highly cell-specific control of gene expression. This mRNA could not be detected anywhere else in the developing brain or embryo. Thus, $\alpha_{6}$ gene expression could be used as a unique indicator for cerebellar granule cells, although, in cultured hippocampal neurons, the suppression of $\alpha_{6}$ expression can be overridden temporarily (Killisch et al., 1991). Diazepam-resistant ${ }^{3} \mathrm{H}$-Ro15-4513 binding, a feature of $\alpha_{6} \beta_{x} \gamma_{2}$ receptors (Lüddens et al., 1990), appears in the cerebellar granule cell layer after P6 (Uusi-Oukari et al., 1991; D. J. Laurie, unpublished observations), coinciding with the production of $\alpha_{6}$ mRNA. Whereas moderate $\mathrm{BZ}$ binding is present in neonatal cerebellum, ${ }^{3} \mathrm{H}-$ muscimol and ${ }^{3} \mathrm{H}-\mathrm{GABA}$ binding only begins $1-2$ weeks after birth (Coyle and Enna, 1976; Palacios and Kuhar, 1982). This temporal disparity is similar to that in the cortex and may have a similar basis.

\section{Other brain structures: thalamus, globus pallidus, medial septum, and spinal cord}

In the developing thalamus there is a dramatic and almost complete switch of GABA $\mathrm{A}_{\mathrm{A}}$ subunit gene expression from $\alpha_{2}, \alpha_{3}, \alpha_{4}$, $\alpha_{5}, \beta_{1}, \beta_{3}, \gamma_{1}, \gamma_{2}$, and $\gamma_{3}$ mRNAs in specific nuclei, to a virtually homogeneous adult expression of $\alpha_{1}, \alpha_{4}, \beta_{2}$, and $\delta$ mRNAs (Table 2; see Wisden et al., 1992, for discussion of adult thalamic receptors). Thalamic receptors should therefore bind $\mathrm{GABA}_{\mathrm{A}}$ ligands at all ages but should lose affinity for BZ analogs (Pritchett et al., 1989b; Ymer et al., 1990; Puia et al., 1991; Herb et

hippocampus (CA1 + CA3); triangles, thalamus (all nuclei). Nonspecific hybridization consistently gave signals on the same autoradiograms of optical density $<0.08$. 
al., 1992), due to the predicted decline of thalamic $\gamma$ subunit production. The large number of transcripts in the early thalamus makes simple predictions of $\mathrm{GABA}_{\mathrm{A}}$ receptor subunit composition impossible. However, in the globus pallidus an obvious developmental switch in the few transcripts expressed allows the deduction of $\alpha_{2} \beta_{2} \gamma_{1}$ and $\alpha_{1} \beta_{2} \gamma_{1} / \gamma_{2}$ assemblies in the neonate and adult, respectively. Similarly, GABA $A_{A}$ receptor composition in the medial septum should change from $\alpha_{2} / \alpha_{3} \beta_{2} \gamma_{2}$ to $\alpha_{1} \beta_{2} \gamma_{2}$. Exchange of $\alpha_{1}$ for $\alpha_{2}$ or $\alpha_{3}$, and $\gamma_{1}$ for $\gamma_{2}$ in recombinant $\alpha \beta \gamma$ receptors drastically alters their responses to GABA and BZ agonists and inverse agonists (Ymer et al., 1990; Puia et al., 1991). Thus, these combinatorial switches in the globus pallidus and medial septum should significantly change $\mathrm{GABA}_{\mathrm{A}}$ receptor properties. In embryonic spinal cord, the strong expression of $\alpha, \beta$, and $\gamma$ genes is consistent with the very high densities ( $\sim 400 \%$ of adult) of $\mathrm{GABA}_{\mathrm{A}}$ and $\mathrm{BZ}$ binding (type II), which then decline after birth (Saito et al., 1983).

\section{Caudal to rostral expression of subunit genes}

In cell culture, GABA stimulates autodevelopment of its own receptors through $\mathrm{GABA}_{\mathrm{A}}$ sites (Meier et al., 1987). GABAimmunoreactive neurons and fibers are detectable from an embryonic age (E13), appearing first in caudal structures and later in rostral structures and ccrcbcllum (Lauder et al., 1986; Seress and Ribak, 1988; Meinecke and Rakic, 1990; Cobas et al., 1991). Consistent with GABA-promoted development of GABA A $_{A}$ ceptors, fetal subunit transcripts also appear in a caudal to rostral manner (Figs. 1-4), approximately $1 \mathrm{~d}$ after the GABA-immunoreactive fibers (Lauder et al., 1986). Autoradiographic patterns of ${ }^{3} \mathrm{H}$-flunitrazepam binding in the brains of developing rat embryos (Schlump et al., 1983) very closely follow the caudal to rostral appearance of $\gamma_{2}$ mRNA (Figs. 1-6), supporting the proposal, based on in vitro expression studies, that the $\gamma_{2}$ subunit is necessary for high-affinity BZ agonist binding (Pritchett et al., 1989b). In contrast, $\alpha_{3}$ mRNA is already ubiquitously expressed in the E14 brain (Fig. 1), suggesting that its expression is not dependent on GABA and indeed that GABA may stimulate the expression of the other subunits through receptors containing the $\alpha_{3}$ subunit.

\section{Receptors on neuroblasts and embryonic peripheral neurons}

Although the majority of $\mathrm{GABA}_{\mathrm{A}}$ subunit transcripts were restricted to mature postmigratory neurons, expression of some $\left(\alpha_{2}, \alpha_{3}, \beta_{1}, \beta_{3}, \gamma_{1}, \gamma_{2}\right)$ was detected in germinal zones and in migrating neurons. The $\beta_{3}$ transcript has also been noted by others in mitotic zones of the forebrain and cerebellum (Gambarana et al., 1991; Zhang et al., 1991). Mitotic cells in the germinal zones therefore express a variety of $\mathrm{GABA}_{\mathrm{A}}$ genes that is potentially sufficient to form fully functional receptors (Seeburg et al., 1990; Puia et al., 1991), through which GABA could exert neurotrophic or mitotic effects (Hansen ct al., 1987).

GABA has a role in several peripheral organs (Erdo and Wolff, 1990), especially in neuronal signaling. Two embryonic structures strongly expressing $\mathrm{GABA}_{\mathrm{A}}$ transcripts (dorsal root ganglion, trigeminal ganglion) are derived from the neural crest (Jacobson, 1978), indicating a common origin and an association with the CNS. The peripheral localization of several GA$B A_{A}$ subunit transcripts shows the involvement of some subunits in both central and peripheral $\mathrm{GABA}_{\mathrm{A}}$ receptors. The detection of only $\gamma_{3}$ mRNA in intestine suggests that other GA$\mathrm{BA}_{\mathrm{A}}$ subunits may await discovery in the PNS. Whether these expression patterns are maintained into maturity remains to be examined, but $\alpha_{1}, \alpha_{2}, \beta_{2}$, and $\gamma_{2}$ mRNAs are also found in adult dorsal root ganglia (Persohn et al., 1991).

\section{Changing subunit combinations in development}

In the developing rat CNS, a wide range of regional expression schemes are apparent. Subunit mRNAs found in early brain are sometimes conserved (e.g., hypothalamus) or replaced (e.g., thalamus, globus pallidus), other times supplemented (e.g., hippocampus, spinal cord) or deleted (e.g., lateral septum, cerebellar granule cells; Tables 1, 2). Even within a structure, each subunit mRNA often follows a different program (e.g., caudate, globus pallidus, mitral cells; Table 1). The neonatally expressed transcripts may belong to a default expression profile that can be retained (e.g., in hippocampus) or lost (e.g., in thalamus) when other $\mathrm{GABA}_{\mathrm{A}}$ transcripts appear during neuronal maturation.

Based on overlapping mRNA expression profiles, a wide variety of receptor combinations could be formed during development. No two subunit transcripts exhibit identical temporal and spatial patterns. However, the $\alpha_{2}, \alpha_{3}$, and $\alpha_{5}$ transcripts often colocalize in time and region with the $\beta_{3}$ transcript (e.g., Figs. 7,8), while $\alpha_{1}$ and $\beta_{2}$ mRNA often codistribute (Figs. 11-14). These are not absolute relationships, as, for example, in the young cortex and globus pallidus $\beta_{2}$ and $\beta_{3}$ mRNAs are found with $\alpha_{2}$ and $\alpha_{3}$ mRNAs (Figs. 9, 10), and the expression of the $\beta_{2}$ transcript in several regions precedes that of $\alpha_{1}$. Although the $\alpha_{5}$ and $\beta_{1}$ mRNA expressions are markedly different at perinatal stages (Figs. 3-10), there is a gradual convergence over time such that by $\mathrm{P} 12$ and beyond, the distributions are very similar (Figs. 11-14) (except in olfactory bulb), suggesting the $\alpha_{5} \beta_{1}$ combination as a mature pairing. Similarly, the sum of the $\alpha_{4}$ and $\alpha_{6}$ mRNA expression patterns shows a strong similarity to that of the $\delta$ transcript, although the expression of the latter lags behind that of the former two. The $\alpha_{1} \beta_{2}, \alpha_{2} \beta_{3}, \alpha_{5} \beta_{1}, \alpha_{4} \delta$, and $\alpha_{6} \delta$ pairings have already been suggested by us from their mRNA distributions in the adult rat brain (Laurie et al., 1992; Wisden et al., 1992), and the present study adds some weight to these combinatorial proposals.

A variety of other regionally specific combinations are also possible, and subunits may proceed through a series of partnerships before converging to final adult assemblies. The spatial and temporal expression patterns of the $\gamma$ subunit mRNAs did not follow the pattern of any $\alpha, \beta$, or $\delta$ subunit transcript. Based on mRNA levels, the $\gamma_{2}$ subunit should participate in many adult and neonatal $\mathrm{GABA}_{\mathrm{A}}$ receptors, while the majority of $\mathrm{GABA}_{\mathrm{A}}$ receptors containing the $\gamma_{1}$ and $\gamma_{3}$ subunits would be found perinatally. However, there are certain areas in the adult rat brain (e.g., medial amygdala, septum, Bergmann glia) where $\gamma_{1}$ gene expression remains substantially elevated (Laurie et al., 1992; Wisden et al., 1992). The $\gamma$ subunits therefore appear more promiscuous than members of the $\alpha, \beta$, and $\delta$ classes, and exhibit a variety of partnerships that change with region and alterations in $\alpha$ and $\beta$ expression (e.g., $\alpha_{3} \beta_{3} \gamma_{2}$ and $\alpha_{1} \beta_{2} \gamma_{2}$ in neonatal and mature cortex).

The intensity of $\alpha_{2}, \alpha_{3}$, and $\alpha_{5}$ subunit gene expression in P6 brain (Fig. 9) contrasts with the more limited expression of $\beta$ and $\gamma$ subunit genes (Fig. 10). If the corresponding protein levels are in proportion, there might be a surplus of these $\alpha$ subunits unless they combine with other, as yet unidentified, $\mathrm{GABA}_{\mathrm{A}}$ subunits such as a possible rodent homolog of the avian $\beta_{4}$ subunit (Bateson et al., 1991). Alternatively, an excess of $\alpha$ 
subunits may promote the assembly of heteromeric $\mathrm{GABA}_{\mathrm{A}}$ receptor complexes.

\section{Rationale for subunit gene expression changes}

The changes of $\mathrm{GABA}_{\mathrm{A}}$ subunit mRNA expression imply a rationale for the receptor combinations at each age. The most marked change in expression occurs for the $\alpha$ subunit mRNAs (Tables 1,2), which may occur as a result of the changing role of GABA during development. Until P8-P12, GABA apparently mediates neuronal depolarization through $\mathrm{GABA}_{\mathrm{A}}$ receptors rather than hyperpolarization as found in the adult brain (Ben-Ari et al., 1989; reviewed by Cherubini et al., 1991). This difference is thought to be due to opposite electrochemical chloride gradients. The perinatal neurotrophic action of GABA, probably released from growth cones (Gordon-Weeks et al., 1984), could be related to the GABA-induced depolarization and subsequent calcium ion entry via voltage-sensitive calcium channels (Connor et al., 1987; Hansen et al., 1987; Wolff et al., 1987; Spitzer, 1991; Yuste and Katz, 1991). This GABA-induced elevation of basal intracellular calcium levels can persist for several minutes and may result in development and/or modification of future inhibitory synapses (Yuste and Katz, 1991).

Mature synapse formation in rat brain principally occurs in the third and fourth postnatal weeks (Aghajanian and Bloom, 1967). Thus, most $\mathrm{GABA}_{\mathrm{A}}$ receptors present on neurons before this age would be expected to be extrasynaptic. For GABA to exert a neurotrophic effect, such receptors may have to exhibit greater sensitivity to GABA than those eventually located in synapses, because perinatal $\mathrm{GABA}_{A}$ binding is unusually low, and because ambient concentrations of GABA would probably be lower than those later occurring in synaptic clefts. Thus, GABA should be more efficacious at fetal and neonatal $\mathrm{GABA}_{\mathrm{A}}$ receptors (mainly containing $\alpha_{2}, \alpha_{3}$, or $\alpha_{5}$ ) than at those of the adult (mainly containing $\alpha_{1}$ ). Such a hypothesis fits nicely with electrophysiological data indicating that recombinant $\alpha_{3} \beta_{2} \gamma_{2}$ and $\alpha_{5} \beta_{2} \gamma_{2}$ receptors exhibit greatcr sensitivity to GABA than do $\alpha_{1} \beta_{2} \gamma_{2}$ receptors, and similarly that GABA is more potent on $\alpha_{2} \beta_{1}$ and $\alpha_{5} \beta_{1}$ combinations than on $\alpha_{1} \beta_{1}$ assemblies (Levitan et al., 1988; Malherbe et al., 1990; Sigel et al., 1990).

Genesis of mature-type synapses accelerates dramatically after P12 (Aghajanian and Bloom, 1967), at which stage GABA is proposed to become an inhibitory transmitter (Kriegstein et al., 1987; Ben-Ari et al., 1989; Swann et al., 1989; reviewed by Cherubini et al., 1991). As a consequence of the increasing synaptic localization of $\mathrm{GABA}_{\mathrm{A}}$ receptors, such high efficacy of GABA would no longer be required and more assemblies could begin to contain $\alpha_{1}$ subunits. The depolarizing and neurotrophic actions of GABA (protein synthesis, neurite/axon extension, synaptogenesis) may therefore be mediated through $\mathrm{GABA}_{\mathrm{A}}$ receptors constructed from a perinatal group of subunits (e.g., $\left.\alpha_{2}, \alpha_{3}, \alpha_{5}, \beta_{3}, \gamma_{2}\right)$ until mature-type neuronal connections are establishcd. It is of interest that in the adult hippocampus, which also contains predominantly $\alpha_{2}$ and $\alpha_{5}$ mRNAs, GABA $_{\mathrm{A}}$ receptors operate both hyperpolarizing and depolarizing chloride currents (Wong and Watkins, 1982; Michelson and Wong, 1991).

\section{Summary and conclusions}

We have demonstrated by film and slide-emulsion autoradiography that all $\mathrm{GABA}_{\mathrm{A}}$ subunit genes exhibit different developmental expression patterns in rat brain. Based on our observations in the cortex, hippocampus, and thalamus, it seems likely that $\mathrm{GABA}_{\mathrm{A}}$ receptors are expressed on many telence- phalic and mesencephalic neurons as soon as they cease migration. $\mathrm{GABA}_{\mathrm{A}}$ receptors in the perinatal brain are proposed to contain combinations of $\alpha_{2}, \alpha_{3}, \alpha_{5}, \beta_{1}, \beta_{2}, \beta_{3}, \gamma_{1}, \gamma_{2}$, and $\gamma_{3}$ subunits. These receptors are often superseded in the adult by others containing $\alpha_{1}, \alpha_{4}, \alpha_{6}, \beta_{2}, \gamma_{2}$, and $\delta$ subunits, except in some regions such as hippocampus that in maturity express both neonatal and adult receptor forms. The combinations of $\alpha_{1} \beta_{2}, \alpha_{2} \beta_{3}$, $\alpha_{4} \delta$, and $\alpha_{6} \delta$ are largely conserved during development, while the $\alpha_{5} \beta_{1}$ pairing converges over time. Based on mRNA levels, the $\gamma$ subunits could combine with whatever $\alpha$ and $\beta$ subunits are coexpressed in cells. The events controlling each spatial and temporal gene expression pattern are unknown, but the lateappearing transcripts $\left(\alpha_{1}, \alpha_{4}, \alpha_{6}, \beta_{2}, \delta\right)$ coincide with the genesis of mature synapses. Receptors for many other transmitter systems (e.g., glycine, glutamate, 5-HT) also undergo marked changes in gene expression during rat brain development (Malosio et al., 1991; Monyer et al., 1991; Spitzer, 1991; Voigt et al., 1991). Any ontogenetic effects of the GABAergic system most likely involve interactions with these other systems as well. A better understanding of why these changes should occur during brain development, and what significance these may have in terms of the function and pharmacological manipulation of the fetal and neonatal GABAergic systems, is an intriguing prospect.

\section{Appendix}

\section{List of anatomical abbreviations}

\begin{tabular}{|c|c|}
\hline A & Amygdala \\
\hline $\mathrm{Cb}$ & Cerebellum \\
\hline $\mathrm{cb}$ & Fetal cerebellum \\
\hline $\mathrm{cf}$ & Cephalic flexure \\
\hline $\mathrm{Cl}$ & Claustrum \\
\hline $\mathrm{Co}$ & Colliculi \\
\hline co & Fetal colliculi \\
\hline $\mathrm{cp}$ & Cortical plate \\
\hline $\mathrm{CPu}$ & Caudate putamen \\
\hline Ctx & Neocortex \\
\hline $\mathrm{cx}$ & Fetal cortex \\
\hline d & Spinal cord, dorsal \\
\hline DG & Dentate gyrus \\
\hline di & Diencephalon \\
\hline DRG & Dorsal root ganglia \\
\hline eg & External granule cell layer \\
\hline ER & Entorhinal cortex \\
\hline gl & Glomerular layer \\
\hline GP & Globus pallidus \\
\hline $\mathrm{H}$ & Hippocampus \\
\hline hi & Fctal hippocampus \\
\hline hy & Fetal hypothalamus \\
\hline $\mathrm{i}$ & Intestine \\
\hline ig & Internal granule cell layer \\
\hline $\mathrm{L}$ & Liver (nonspecific labeling) \\
\hline $\mathrm{m}$ & Mitral cell layer \\
\hline mes & Mesencephalon \\
\hline met & Metencephalon \\
\hline $\mathrm{mg} / \mathrm{MG}$ & Medial geniculate nucleus \\
\hline mol & Molecular layer \\
\hline $\mathrm{ms}$ & Medial septum \\
\hline my & Myelencephalon \\
\hline ne & Nasal epithelium \\
\hline $\mathrm{OB}$ & Olfactory bulb \\
\hline ob & Fetal olfactory bulb \\
\hline $\mathrm{p}$ & Purkinje cell layer \\
\hline pt & Fetal pretectal area \\
\hline $\mathrm{r}$ & reticular thalamic nucleus \\
\hline $\mathbf{S}$ & Septum \\
\hline sc & Fetal spinal cord \\
\hline st & Fetal striatum \\
\hline $\mathbf{T}$ & Thalamus \\
\hline
\end{tabular}


t Fetal thalamus

te Telencephalon

TG Trigeminal ganglion

v Spinal cord, ventral

vz Ventricular zone

\section{References}

Aghajanian GK, Bloom FE (1967) The formation of synaptic junctions in developing rat brain: a quantitative electron microscopic study. Brain Res 6:716-727.

Aicardi J, Chevrie JJ (1970) Convulsive status epilepticus in infants and children. A study of 239 cases. Epilepsia 11:189-197.

Bateson AN, Lasham A, Darlison MG (1991) $\gamma$-Aminobutyric acid receptor heterogeneity is increased by alternative splicing of a novel $\beta$-subunit gene transcript. J Neurochem 56:1437-1440.

Ben-Ari Y, Cherubini E, Corradetti R, Gaiarsa J-L (1989) Giant synaptic potentials in immature rat CA3 hippocampal neurones. J Physiol (Lond) 416:303-325.

Benke D, Mertens S, Trzeciak A, Gillessen D, Möhler H (1991) GA$\mathrm{BA}_{\mathrm{A}}$ receptors display association of $\gamma_{2}$ subunit with $\alpha_{1^{-}}$and $\beta_{2 / 3^{-}}$ subunits. J Biol Chem 266:4478-4483.

Candy JM, Martin IL (1979) The postnatal development of the benzodiazepine receptor in the cerebral cortex and cerebellum of the rat J Neurochem 32:655-658.

Cherubini E, Gaiarsa J-L, Ben-Ari Y (1991) GABA: an excitatory transmitter in early postnatal life. Trends Neurosci 14:515-519.

Chisholm J, Kellogg C, Lippa A (1983) Development of benzodiazepine binding subtypes in three regions of rat brain. Brain Res 267: 388-391.

Cobas A, Fairen A, Alvarez-Bolado G, Sanchez MP (1991) Prenatal development of the intrinsic neurons of the rat neocortex: a comparative study of the distribution of GABA-immunoreactive cells and the GABA A $_{\text {. }}$ receptor. Neuroscience 40:375-397.

Connor JA, Tseng H-Y, Hockberger PE (1987) Depolarization- and transmitter-induced changes in intracellular $\mathrm{Ca}^{2+}$ of rat cerebellar granule cells in explant cultures. J Neurosci 7:1384-1400.

Coyle JT, Enna SJ (1976) Neurochemical aspects of the ontogenesis of GABAnergic neurons in the rat brain. Brain Res 111:119-133.

Eichinger A, Sieghart W (1986) Postnatal development of proteins associated with different benzodiazepine receptors. J Neurochem 46 : 173-180.

Erdo SL, Wolff JR (1990) $\gamma$-Aminobutyric acid outside the mammalian brain. J Neurochem 54:363-372.

Fuchs K, Adamiker D, Sieghart W (1990) Identification of $\alpha_{2}$ and $\alpha_{3}$ subunits of the $\mathrm{GABA}_{\mathrm{A}}$-benzodiazepine receptor complex purified from the brains of young rats. FEBS Lett 261:52-54.

Gambarana C, Pittman R, Siegel RE (1990) Developmental expression

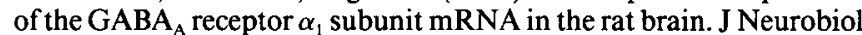
21:1169-1179.

Gambarana C, Beattie CE, Rodriguez ZR, Siegel RE (1991) Regionspecific expression of messenger RNAs encoding $G A B A_{A}$ receptor subunits in the developing rat brain. Neuroscience 45:423-432.

Garrett KM, Saito N, Duman RS, Abel MS, Ashton RA, Fujimori S, Beer B, Tallmann JF, Vitek MP, Blume $\Lambda$ J (1990) Differential ex-

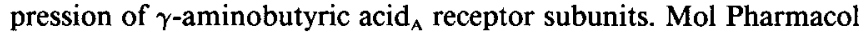
37:652-657.

Gordon-Weeks PR, Lockerbie RO, Pearce BR (1984) Uptake and release of $\left[{ }^{3} \mathrm{H}\right] \mathrm{GABA}$ by growth cones isolated from neonatal rat brain. Neurosci Lett 52:205-210.

Hansen GH, Meier E, Abraham J, Schousboe A (1987) Trophic effects of GABA on cerebellar granule cells in culture. In: Neurology and neurobiology, Vol 32, Neurotrophic activity of GABA during development (Redburn DA, Schousboe A, eds), pp 109-138. New York: Liss.

Herb A, Wisden W, Iüddens H, Puia G, Vicini S, Seeburg PH (1992) A third $\gamma$ subunit of the GABA a receptor family. Proc Natl Acad Sci USA 89:1433-1437.

Jacobson M (1978) Developmental neurobiology, 2d ed. New York: Plenum.

Jones EG (1985) The thalamus. New York: Plenum.

Kater SB, Guthrie PB (1990) Neuronal growth cone as an integrator of complex environmental information. Cold Spring Harbor Symp Quant Biol 55:359-370.

Kellogg CK (1988) Benzodiazepine influences on the developing brain. Prog Brain Res 73:207-228.
Kellogg CK, Pfleger GL (1989) GABA-stimulated chloride uptake and enhancement by diazepam in synaptoneurosomes from rat brain during prenatal and postnatal development. Dev Brain Res 49:87-95.

Khrestchatisky M, MacLennan AJ, Chiang M-Y, Xu W, Jackson MB, Brecha N, Sternini C, Olsen RW, Tobin AJ (1989) A novel $\alpha$ subunit in rat brain $\mathrm{GABA}_{\mathrm{A}}$ receptors. Neuron 3:745-753.

Killisch I, Dotti CG, Laurie DJ, Lüddens H, Seeburg PH (1991) Expression patterns of $\mathrm{GABA}_{\mathrm{A}}$ receptor subtypes in developing hippocampal neurons. Neuron 7:927-936.

Kriegstein AR, Suppes T, Prince DA (1987) Cellular and synaptic physiology and epileptogenesis of developing rat neocortical neurons in vitro. Dev Brain Res 34:161-171.

Lauder JM, Han VKM, Henderson P, Verdoorn T, Towle AC (1986) Prenatal ontogeny of the GABAergic system in the rat brain: an immunocytochemical study. Neuroscience 19:465-493.

Laurie DJ, Seeburg PH, Wisden W (1992) The distribution of 13 $\mathrm{GABA}_{\mathrm{A}}$ receptor subunit mRNAs in the rat brain. II. Olfactory bulb and cerebellum. J Neurosci 12:1063-1076.

Levitan ES, Schofield PR, Burt DR, Rhee LM, Wisden W, Köhler M, Fujita N, Rodriguez HF, Stephenson A, Darlison MG, Barnard EA, Seeburg PH (1988) Structural and functional basis for $\mathrm{GABA}_{\mathrm{A}}$ receptor heterogeneity. Nature 335:76-79.

Lippa AS, Beer B, Sano MC, Vogel RA, Meyerson LR (1981) Differential ontogeny of type 1 and type 2 benzodiazepine receptors. Life Sci 28:2343-2347.

Lüddens H, Wisden W (1991) Function and pharmacology of multiple $\mathrm{GABA}_{\mathrm{A}}$ receptor subunits. Trends Pharmacol Sci 12:49-51.

Lüddens $H$, Pritchett DB, Köhler M, Killisch I, Keinänen K, Monyer H, Sprengel R, Seeburg PH (1990) Cerebellar GABA A $_{A}$ receptor selective for a behavioural alcohol antagonist. Nature 346:648-651.

MacLennan AJ, Brecha N, Khrestchatisky M, Sternini C, Tillakaratne NJK, Chiang M-Y, Anderson K, Lai M, Tobin AJ (1991) Independent cellular and ontogenetic expression of mRNAs encoding three

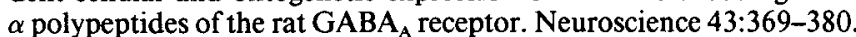

Madtes P (1987) Ontogeny of the GABA receptor complex. In: Neurology and neurobiology, Vol 32, Neurotrophic activity of GABA during development (Redburn DA, Schousboe A, eds), pp 161-188. New York: Liss.

Malherbe P, Sigel E, Baur R, Persohn E, Richards JG, Möhler H (1990) Functional expression and sites of gene transcription of a novel $\alpha$ subunit of the GABA receptor in rat brain. FEBS Lett 260:261-265.

Malosio M-L, Marqueze-Pouey B, Kuhse J, Betz H (1991) Widespread expression of glycine receptor subunit mRNAs in the adult and developing rat brain. EMBO J 10:2401-2409.

McKernan RM, Cox P, Gillard NP, Whiting P (1991a) Differential expression of $\mathrm{GABA}_{\mathrm{A}}$ receptor $\alpha$-subunits in rat brain during development. FEBS Lett 286:44-46.

McKernan RM, Quirk K, Prince R, Cox PA, Gillard NP, Ragan CI, Whiting $P$ (1991b) $\mathrm{GABA}_{\mathrm{A}}$ receptor subtypes immunopurified from rat brain with $\alpha$ subunit-specific antibodies have unique pharmacological properties. Neuron 7:667-676.

Mecarelli O, De Feo MR, Rina MF, Ricci GF (1988) Effects of progabide on bicuculline-induced epileptic seizures in developing rats. Clin Neuropharmacol 11:443-453.

Meier E, Belhage B, Drejer J, Schousboc A (1987) The expression of GABA receptors on cultured cerebellar granule cells is influenced by GABA. In: Neurology and neurobiology, Vol 32, Neurotrophic activity of GABA during development (Redburn DA, Schousboe A, eds), pp 139-160. New York: Liss.

Meinecke DL, Rakic P (1990) Developmental expression of GABA and subunits of the $\mathrm{GABA}_{\mathrm{A}}$ receptor complex in an inhibitory synaptic circuit in the rat cerebellum. Dev Brain Res 55:73-86.

Michelson HB, Wong RKS (1991) Excitatory synaptic responses mediated by $\mathrm{GABA}_{\mathrm{A}}$ receptors in the hippocampus. Science $253: 1420$ 1423.

Miller MW (1988) Development of projection and local circuit neurons in neocortex. In: Cerebral cortex, Vol 7, Development and maturation of cerebral cortex (Peters A, Jones E, eds), pp 133-176. London: Plenum.

Montpied P, Ginns EI, Martin BM, Stetler D, O'Carroll A-M, Lolait

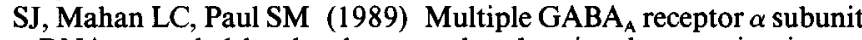
mRNAs revealed by developmental and regional expression in rat, chicken and human brain. FEBS Lett 258:94-98.

Monyer H, Seeburg PH, Wisden W (1991) Glutamate-operated channels: developmentally early and mature forms arise by alternative splicing. Neuron 6:799-810. 
Niddam R, Dubois A, Scatton B, Arbilla S, Langer SZ (1987) Autoradiographic localization of $\left[{ }^{3} \mathrm{H}\right]$ zolpidem binding in the rat CNS. Comparison with the distribution of $\left[{ }^{3} \mathrm{H}\right] f$ lunitrazepam binding sites. J Neurochem 49:890-899.

Olsen RW, Tobin AJ (1990) Molecular biology of GABA A receptors. FASEB J 4:1469-1480.

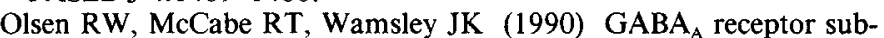
types: autoradiographic comparison of GABA, benzodiazepine, and convulsant binding sites in the rat central nervous system. J Chem Neuroanat 3:59-76.

Oppenheim RW (1991) Cell death during development of the nervous system. Annu Rev Neurosci 14:453-501.

Palacios JM, Kuhar MJ (1982) Ontogeny of high-affinity GABA and benzodiazepine receptors in the rat cerebellum: an autoradiographic study. Dev Brain Res 2:531-539.

Palacios JM, Nichoff DL, Kuhar MJ (1979) Ontogeny of GABA and benzodiazepine receptors: effects of Triton X-100, bromide and muscimol. Brain Res 179:390-395.

Paxinos G, Watson C (1986) The rat brain in stereotaxic coordinates, 2d ed. Sydney: Academic.

Paxinos G, Törk I, Tecott LH, Valentino KL (1991) Atlas of developing rat brain. San Diego: Academic.

Persohn E, Malherbe P, Richards JG (1991) In situ hybridization histochemistry reveals a diversity of $\mathrm{GABA}_{\mathrm{A}}$ receptor subunit mRNAs in neurons of the rat spinal cord and dorsal root ganglia. Neuroscience 42:497-507.


subunit creates novel type II benzodiazepine receptor pharmacology. J Neurochem 54:1802-1804.

Pritchett DB, Lüddens H, Sccburg PH (1989a) Typc I and typc II $\mathrm{GABA}_{\mathrm{A}}$ benzodiazepine receptors produced in transfected cells. Science 246:1389-1392.

Pritchett DB, Sontheimer H, Shivers BD, Ymer S, Kettenmann H, Schofield PR, Seeburg PH (1989b) Importance of a novel GABA receptor subunit for benzodiazepine pharmacology. Nature 338:582585.

Puia G, Vicini S, Seeburg PH, Costa E (1991) Influence of recombinant

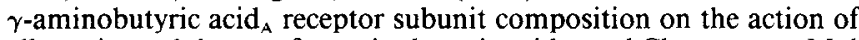
allosteric modulators of $\gamma$-aminobutyric acid-gated $\mathrm{Cl}^{-}$currents. Mol Pharmacol 39:691-696.

Reichelt R, Hofmann D, Fodisch H-J, Mohler H, Knapp M, Hebebrand $J$ (1991) Ontogeny of the benzodiazepine receptor in human brain: fluorographic, immunochemical and reversible binding studies. J Neurochem 57:1128-1135.

Rugh $R$ (1991) The mouse. Its reproduction and development. New York: Oxford UP.

Saito K, Goto M, Fukuda H (1983) Postnatal development of the benzodiazepine and GABA receptors in rat spinal cord. Jpn J Pharmacol 33:906-909.

Sato N, Neale JH (1989) Type I and type II $\gamma$-aminobutyric acid/ benzodiazepine receptors: purification and analysis of novel receptor complex from neonatal cortex. J Neurochem 52:1114-1122.

Schlumpf M, Richards JG, Lichtensteiger W, Mohler H (1983) An autoradiographic study of the prenatal development of benzodiazepine-binding sites in rat brain. $J$ Neurosci 3:1478-1487.

Seeburg PH, Wisden W, Verdoorn TA, Pritchett DB, Werner P, Herb A, Lüddens H, Sprengel R, Sakmann B (1990) The GABA receptor family: molecular and functional diversity. Cold Spring Harbor Symp Quant Biol 55:29-40.

Seress L, Ribak CE (1988) The development of GABAergic neurons in the hippocampal formation. An immunocytochemical study. Dev Brain Res 44:197-209.

Sieghart W (1986) Comparison of benzodiazepine receptors in cerebellum and inferior colliculus. J Neurochem 47:920-923.

Sieghart W, Schlerka W (1991) Potency of several type I-benzodiazepine receptor ligands for inhibition of $\left[{ }^{3} \mathrm{H}\right]$ flunitrazepam binding in different rat brain tissues. Eur J Pharmacol 197:103-107.

Sigel E, Baur R, Trube G, Möhler H, Malherbe P (1990) The effect of subunit composition of rat brain $\mathrm{GABA}_{\mathrm{A}}$ receptors on channel function. Neuron 5:703-711.

Simmons RD, Kellogg CK, Miller RK (1984a) Prenatal diazepam cxposure in rats: long-lasting receptor-mediated effects on hypothalamic norepinephrine-containing neurons. Brain Res 293:73-83.

Simmons RD, Miller RK, Kellogg CK (1984b) Prenatal exposure to diazepam alters central and peripheral responses to stress in adult rat offspring. Brain Res 307:39-46.

Spitzer NC (1991) A developmental handshake: neuronal control of ionic currents and their control of neuronal differentiation. J Neurobiol 22:659-673.

Stanfield BB, Cowan WM (1988) The development of the hippocampal region. In: Cerebral cortex, Vol 7, Development and maturation of cerebral cortex (Peters A, Jones E, eds), pp 91-126. London: Plenum.

Swann JW, Brady RJ, Martin DL (1989) Postnatal development of GABA-mediated synaptic inhibition in rat hippocampus. Neuroscience 28:551-561.

Turner DM, Sapp DW, Olsen RW (1991) The benzodiazepine/alcohol antagonist Ro 15-4513: binding to a $\mathrm{GABA}_{\mathrm{A}}$ receptor subtype that is insensitive to diazepam. J Pharmacol Exp Ther 257:1236-1242.

Unnerstall JR, Kuhar MJ, Niehoff DL, Palacios JM (1981) Benzodiazepine receptors are coupled to a subpopulation of GABA receptors: evidence from a quantitative autoradiographic study. J Pharmacol Exp Ther 218:797-804.

Unwin N (1989) The structure of ion channels in membranes of excitable cells. Neuron 3:665-676.

Uusi-Oukari M, Korpi ER, Kaivola J, Wegelius K (1991) Binding of Ro 15-4513 to cerebellar membranes: ontogeny and substrate specificity. Soc Neurosci Abstr 17:77.

Vitorica J, Park D, Chin G, de Blas AL (1990) Characterization with antibodies of the $\gamma$-aminobutyric $\operatorname{acid}_{A} /$ benzodiazepine receptor complex during development of the rat brain. J Neurochem 54:187-194.

Voigt MM, Laurie DJ, Seeburg PH, Bach A (1991) Molecular cloning and characterization of a rat brain cDNA encoding a 5hydroxytryptamine $_{13}$ receptor. EMBO J 10:4017-4023.

Wisden W, Seeburg PH (1992) GABA receptors: from subunits to functional entities. Curr Opin Neurobiol 2:263-269.

Wisden W, Herb A, Wieland H, Keinänen K, Lüddens H, Seeburg PH (1991a) Cloning, pharmacological characteristics and expression pattern of the rat GABA ${ }_{\mathrm{A}}$ receptor $\alpha_{4}$ subunit. FEBS Lett 289:227-230.

Wisden W, Morris BJ, Hunt SP (1991b) In situ hybridization with synthetic DNA probes. In: Molecular neurobiology-a practical approach (Chad J, Wheal H, eds), pp 205-226. Oxford: IRL.

Wisden W, Laurie DJ, Monyer M, Seeburg PH (1992) The distribution of 13 GABA receptor subunit mRNAs in the rat brain. I. Telencephalon, diencephalon, mesencephalon. J Neurosci 12:1040-1062.

Wolff JR, Joo F, Kasa P (1987) Synaptic, metabolic, and morphogenetic effects of GABA in the superior cervical ganglion of rats. In: Neurology and neurobiology, Vol 32, Neurotrophic activity of GABA during development (Redburn DA, Schousboe A, eds), pp 221-252. New York: Liss.

Wong RKS, Watkins DJ (1982) Cellular factors influencing GABA responses in hippocampal pyramidal cells. J Neurophysiol 48:938945.

Woodward DJ, Hoffer BJ, Siggins GR, Bloom FE (1971) The ontogenic development of synaptic junctions, synaptic activation and responsiveness to neurotransmitter substances in rat cerebellar Purkinje cells. Brain Res 34:73-97.

Ymer S, Draguhn A, Köhler M, Schofield PR, Seeburg PH (1989) Sequence and expression of GABA $\mathrm{A}_{\mathrm{A}}$ receptor $\alpha_{4}$ subunit. FEBS Lett 258:119-122.

Ymer S, Draguhn A, Wisden W, Werner P, Keinänen K, Schofield PR, Sprengel R, Pritchett DB, Seeburg PH (1990) Structural and functional characterization of the $\gamma_{1}$ subunit of $\mathrm{GABA}_{\mathrm{A}} /$ benzodiazepine receptors. EMBO J 9:3261-3267.

Young WS III, Niehoff DL, Kuhar MJ, Beer B, Lippa AS (1981) Multiple benzodiazepine receptor localization by light microscopic radiohistochemistry. J Pharmacol Exp Ther 216:425-436.

Yuste R, Katz LC (1991) Control of postsynaptic $\mathrm{Ca}^{2+}$ influx in developing neocortex by excitatory and inhibitory neurotransmitters. Neuron 6:333-344.

Zdilar D, Rotter A, Frostholm A (1991) Expression of GABA $/$ benzodiazepine receptor $\alpha_{1}$ subunit mRNA and $\left[{ }^{3} \mathrm{H}\right]$ flunitrazepam binding sites during postnatal development of the mouse cerebellum. Dev Brain Res 61:63-71.

Zhang JH, Sato M, Tohyama M (1991) Different postnatal development profiles of neurons containing distinct $\mathrm{GABA}_{\mathrm{A}}$ receptor $\beta$ subunit messenger RNAs $\left(\beta_{1}, \beta_{2}\right.$ and $\left.\beta_{3}\right)$ in the rat forebrain. J Comp Neurol 308:586-613. 